\title{
VERSITA
}

$10.2478 /$ cris-2013-0007

\section{NATURE'S PATTERNS AND GRAPHIC DESIGN}

MARUŠA RAČIČ

Nature is in and around us, the creator of everything that exists. Throughout our evolution, we learned to listen to its language and to collaborate with it to survive.

Looking around us today, it seems that our Western civilization has come to the point where nature, the physical world, has started to drastically lose its presence and meaning in our lives. We are surrounded by concrete and technology and are more and more disconnected from our primal source of existence. Can we create meaningful links with nature in our communications?

This research explores integral parts of nature, its patterns and our connection with them, and discovers their potential meaning for communication in relationship with graphic design. When communicating visually, what graphic design is, we are transforming the meaning of the message from a creator to the viewer. By choosing specific symbols and codes, we can create an appropriate match between the visual presentation and the message. This essay argues that nature's patterns bear universal messages that we understand on a subconscious level. Their inclusion in visual communications can thus transfer intuitively communicated messages and create understandable and fluent relationships with the viewer, which is the core of efficient visual communication.

The primary supportive sources in this paper are various research, evolution theories, and case studies showing examples of graphic design that incorporate natural pattern forms. 
In the earliest examples of primitive humans attempting to express them selves visually, charcoal was used for black paint and warm colours were derived from iron oxides. As a medium for the mixture, fat from animals was utilised. Fingers or simple brushes made from animals' bristles served to apply the colour on the walls of caves (Fig. 1). Abstract geometric shapes were depicted in combination with images of animals (Meggs and Purvis, 2006, p. 4). The purpose of these markings was purely practical; they served the intention of survival (hunting and fertility), ritualism, and "metaphoric evocation that, in this setting, links biological and cosmic time... with its central theme, the creation of the world" (French Ministry of Culture and Communication, cited in Capelo, 2010).

Sitting in front of the computer screen, pressing the plastic buttons of the keyboard, and tracking the mouse cursor in the design programme, creating vector curves, saving the work into a digital folder (Fig. 2); this is the reality of the most common way of creating visual communications today. It seems that we have marginalised our coexistence with nature drastically on all levels and have become addicted to modern, digital driven technologies. We have started to ignore our primal source of all that is the natural, physical world around us, but also the nature within ourselves (Fig. 3).

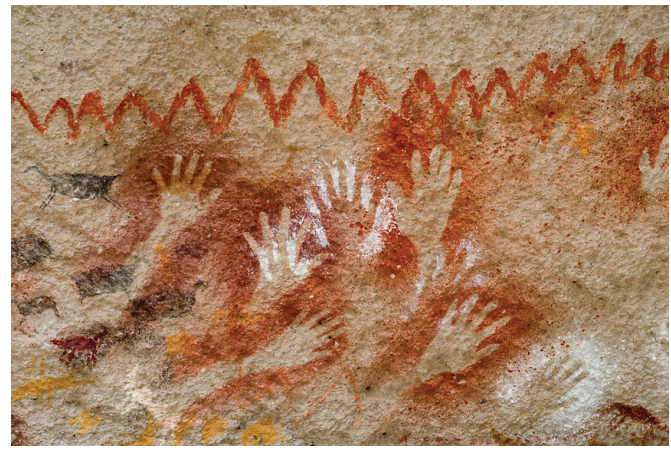

Figure 1: Javier Etcheverry, Geometric Paiting, Rio Pinturas Canyon, Cave of the Hands, Pata, 2010.

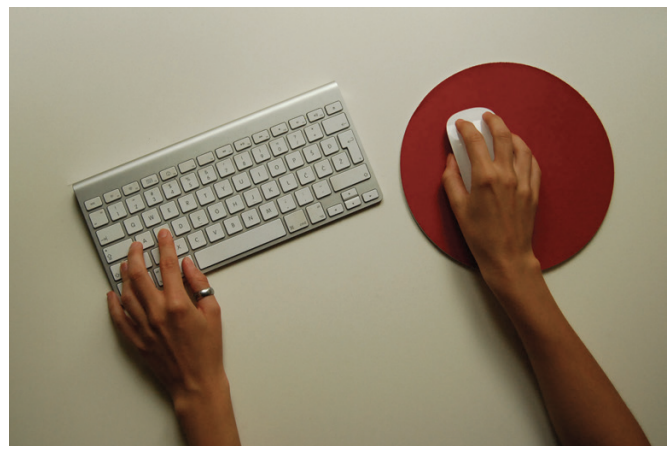

Figure 2: Maruša Račič, Present Day Graphic Designer, 2012.

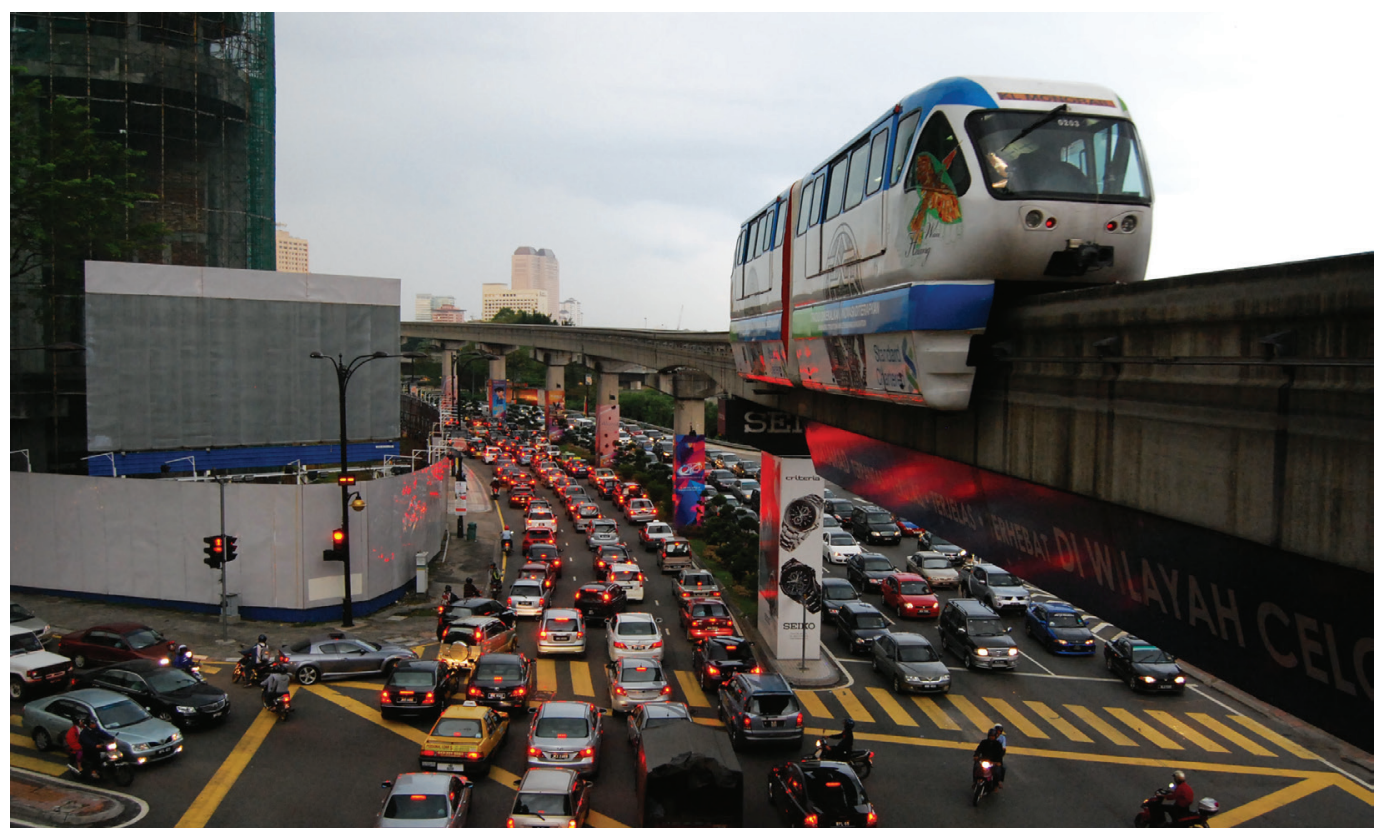

Figure 3: Maruša Račič, Chaos on the Streets of Kuala Lumpur, 2010 


\subsection{TURNING BACK TO NATURE}

In contrast, however, it feels like we have started to become aware of our disconnection with nature and its importance for our existence, so man is again turning back to it more and more. At the beginning of the 21st century, there is a trend towards increased ecological farming (Fig. 4), wide usage of natural materials, and a growing industry for sustainable products (Fig. 5). These are some aspects that clearly depict our desire to bind ourselves with nature again, or at least to find a more harmonious balance between nature and modernity.

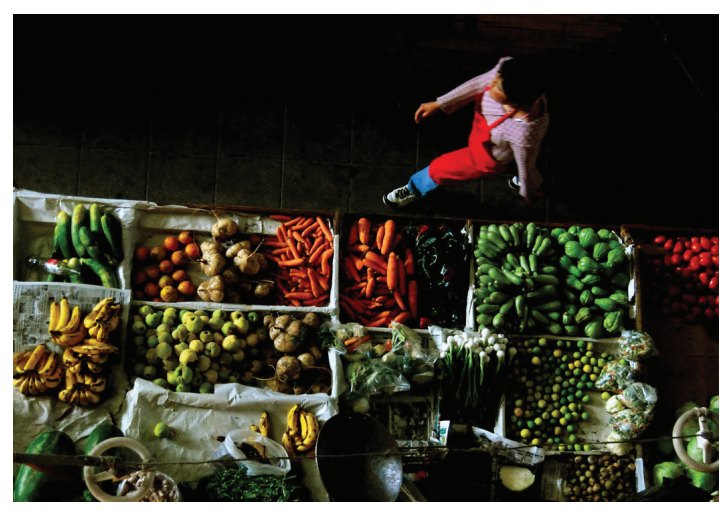

Figure 4: Maruša Račič, Ecologically Grown Food, 2010

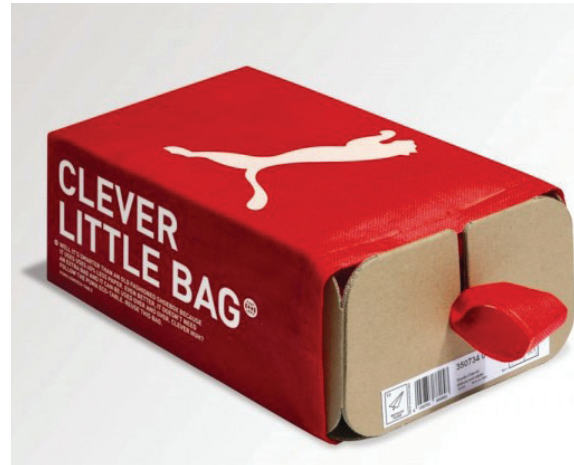

Figure 5: PUMA, Sustainability Efforts, 2010

\subsection{NATURE - A MODEL OF IMITATION AND INSPIRATION}

When it comes to design, nature can be an ideal source. According to Richworks (2011), "hature has managed to create a complex self-sustaining system of life supporting millions of species over billions of years" which can serve as a perfect model for imitation. Macnab (2011, p. 79) agrees, "nature inherently instils beauty, function, and balance."There are many disciplines of design where created work imitates principles and laws of nature, including graphic and product design, interior design, architecture. This model of imitation is examined within the science of biomimicry. Benyus (2002, p. 1) explains biomimicry as a science that "studies nature's models and then imitates or takes inspiration from these designs and processes to solve human problems; e.g., a solar cell inspired by a leaf"(Fig. 6). These solar cells are able to generate almost $50 \%$ more electricity due to their structure. Their surface imitates the branching vein system of a plant's leaves, which enable them to absorb a lot of light (Subha, 2012).

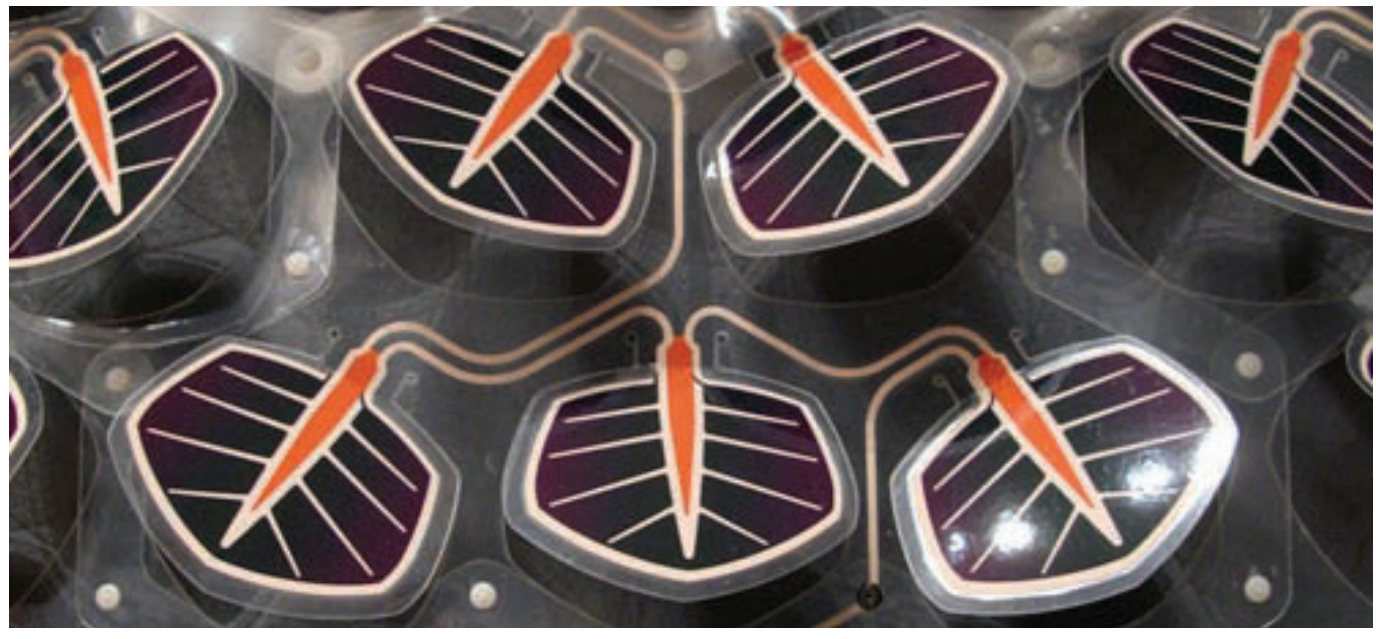

Figure 6: SMIT, Solar cell, inspired by Leaves, 2011. 
The next example is a case of a nature-inspired architecture solution. The Spanish architect, Antoni Gaudí, in his plans for Sagrada Familia, a large Roman Catholic church in Barcelona, came to the idea of forming the upper parts of pillars in a branching way like trees do (Figs. 7-8). Instead of using typical, straight pillars to support the roof of the church nave, he introduced columns that are tree-like; pillars that are branching like a tree that enable it to distribute the carrying weight in optimal support while being extremely thin and elegant, which is one of the distinctive features of the church (La Sagrada Família, 2002).

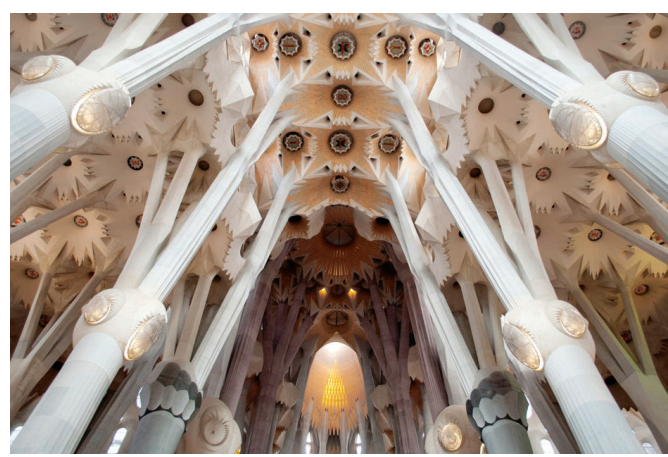

Figure 7: Sagrada Familia, Interior, 2012

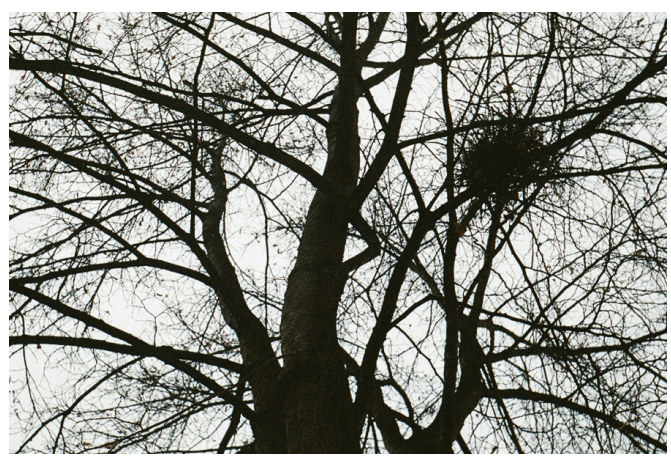

Figure 8: Maruša Račič, A Branching Tree, 2011

\section{THE MEANING OF VISUAL COMMUNICATIONS}

According to Baldwin (2006, p. 12), "design is a form of communication and communication is the basis of our relationships and our understanding of the world." Despite the fact that the tools used by contemporary graphic designers are driven by technological progress and are changing the nature of work drastically, the purpose of visual communications fundamentally remains the same over time (Figs. 9-10). Meggs and Purvis (2006, p. 531) state, "that essence is to give order to information, form to ideas, and expression and feeling to artifacts that document human experience." In graphic design, the connection with nature, in particularly with its patterns, can help us to fulfil the fundamental task of the discipline, to transfer the messages we communicate, as we intuitively know nature's language, because it is happening constantly in and around us and is speaking to us constantly on both the conscious and subconscious level (Macnab, 2012, p. 111).

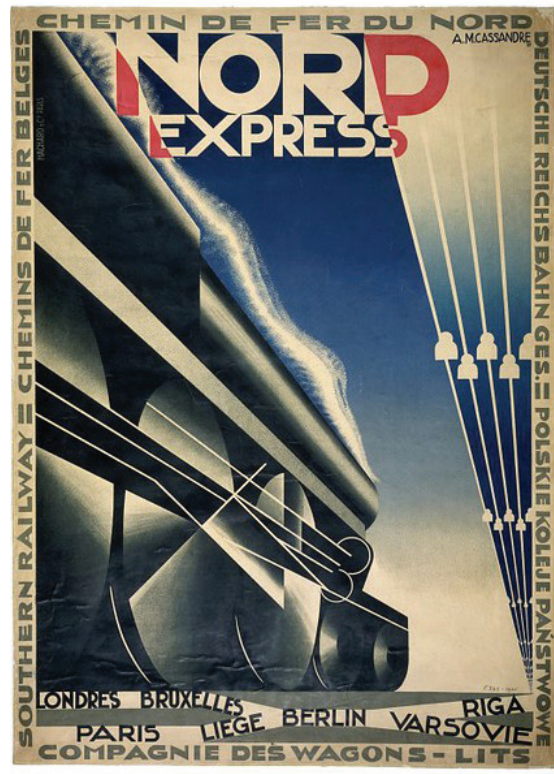

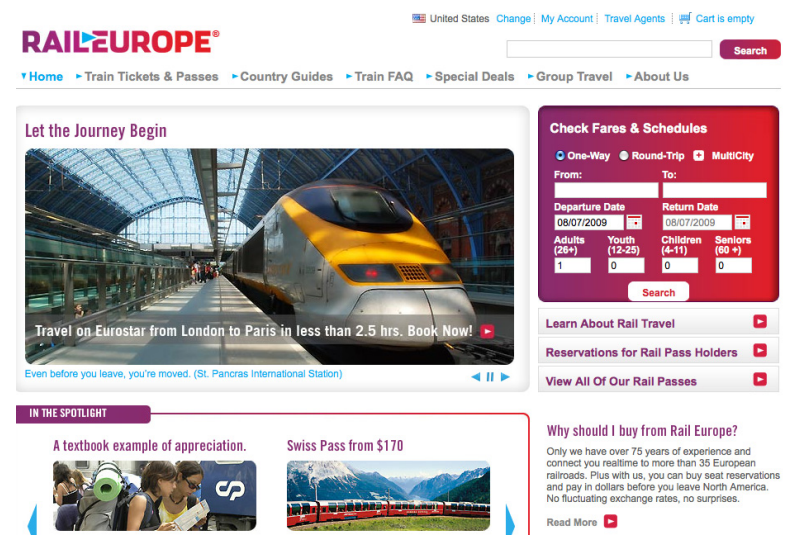

Figure 9 (left): Adolphe Mouron Cassandre, Nord Express, 1927 Figure 10 (right): Rail Europe, Rail Europe Web Site, 2009.

Despite that works the have a significant difference in their style and media used, they have the same purpose - to convince the commuters to use the transport. 


\subsection{EFFECTIVENESS OF VISUAL LANGUAGE}

But why is the expression of ideas and thoughts through visuals as opposed to text and spoken language used so commonly and so effective? When looking back in history again, we can see that textual communication is a relatively new idea (Fig. 11), existing in different forms for about 3700 years, while expressing ideas visually has its roots in a much more distant history (Bathurst, Bathurst and Davies, 1990, cited in Parkinson, 2010, p. 4). Through the process of human evolution, we have genetically developed in a way that we perceive and respond to visual and textual information differently. Johnson (2004, cited in Parkinson, 2010, p. 1) explains, "for example, humans have an innate fondness for images of wide, open landscapes, which evoke an instant sense of well-being and contentment. Psychologists hypothesize that this almost universal response stems from the years our ancestors spent on the savannas in Africa" (Figs. 12). We also perceive visuals much faster then written information. Research, done by $3 \mathrm{M}$ Corporation (Parkinson, 2010, p. 1), showed that our brain processes visual information 60,000 times faster than text. The reason is based on simultaneous perception, while the text is deciphered in a matter of sequences.

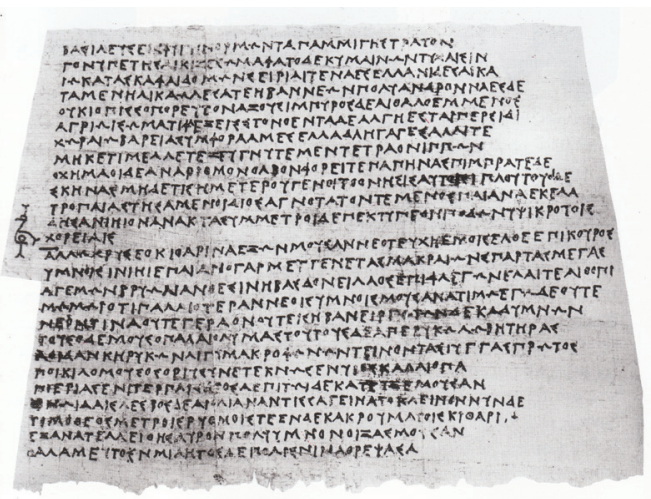

Figure 11: Timotheus, The Persians, c. 400 AD

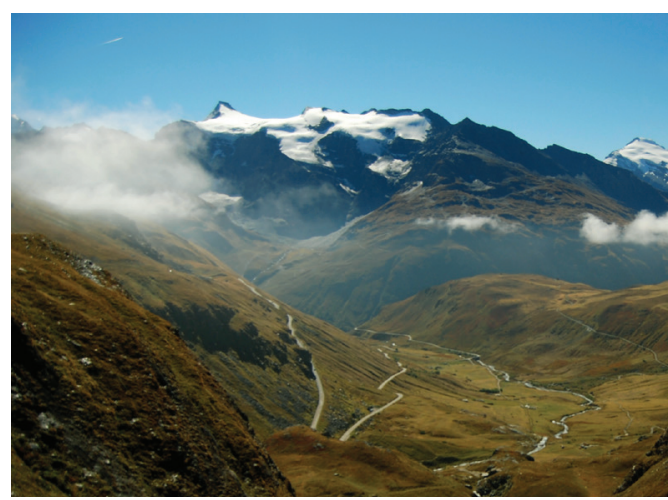

Figure 12: Maruša Račič, Open Landscape I, 2011

\subsection{INCREASED INFORMATION REQUIRES EFFICIENT COMMUNICATION}

It is clear to see that the amount of textual and visual information is constantly increasing as never before. According to Reuter's magazine (2010, cited in Airey, p. 9), during the last 30 years, more information was created than in the 5,000 previous years. Because we are producing such a huge amount of information (Fig. 13), it is important to communicate the desired visual message quickly, clearly, fluently, pleasingly, and meaningfully, so in general, efficiently. Because our world is so globally connected, Macnab (2012, p. 107) suggests, "it is most practical to communicate with messages that have universal relevance."

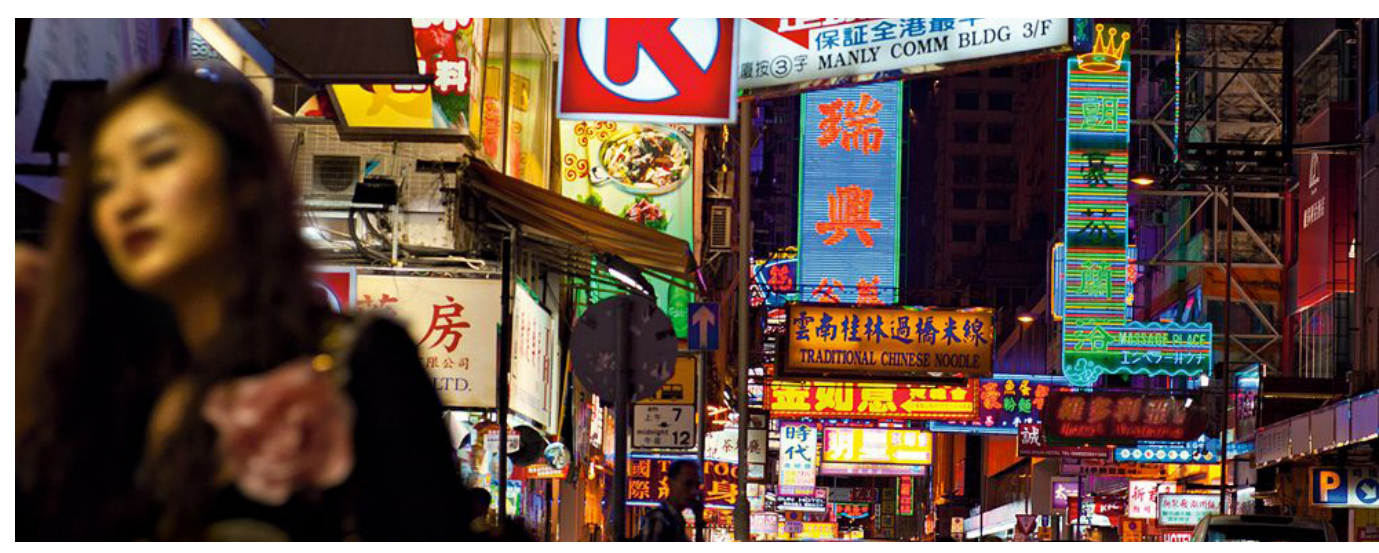

Figure 13: Mark Leong, Mong Kok District, Hong Kong, 2012. 


\subsection{THREE LEVELS OF COMMUNICATION}

According to Shannon and Weaver (2006, cited in Baldwin, p. 22), communication, visual and any other sort, can be discussed from three interconnected levels, technical, semantic, and the level of effectiveness. The technical level deals with questions like which communicating media will be the most effective and which system will be the most appropriate to ' decode' the message. The semantic level considers the aspect of conveying the wanted meaning of the message by choosing the appropriate language, symbols, and codes. Shannon and Weaver (2006, cited in Baldwin, p. 33) assert that "communication is not a process where meaning passes from one point to another, but the production of meaning itself" (Fig. 14). When talking about effectiveness, it concerns the achievement of the desired effect of the message on the public (Shannon and Weaver, 2006, cited in Baldwin, p. 22). The work of a designer is mainly based on the semantic level, as it is carrying the information, trying to convey the meaning of the message without changing it, and possibly to make the message stronger (Macnab, 2012, p. 114).

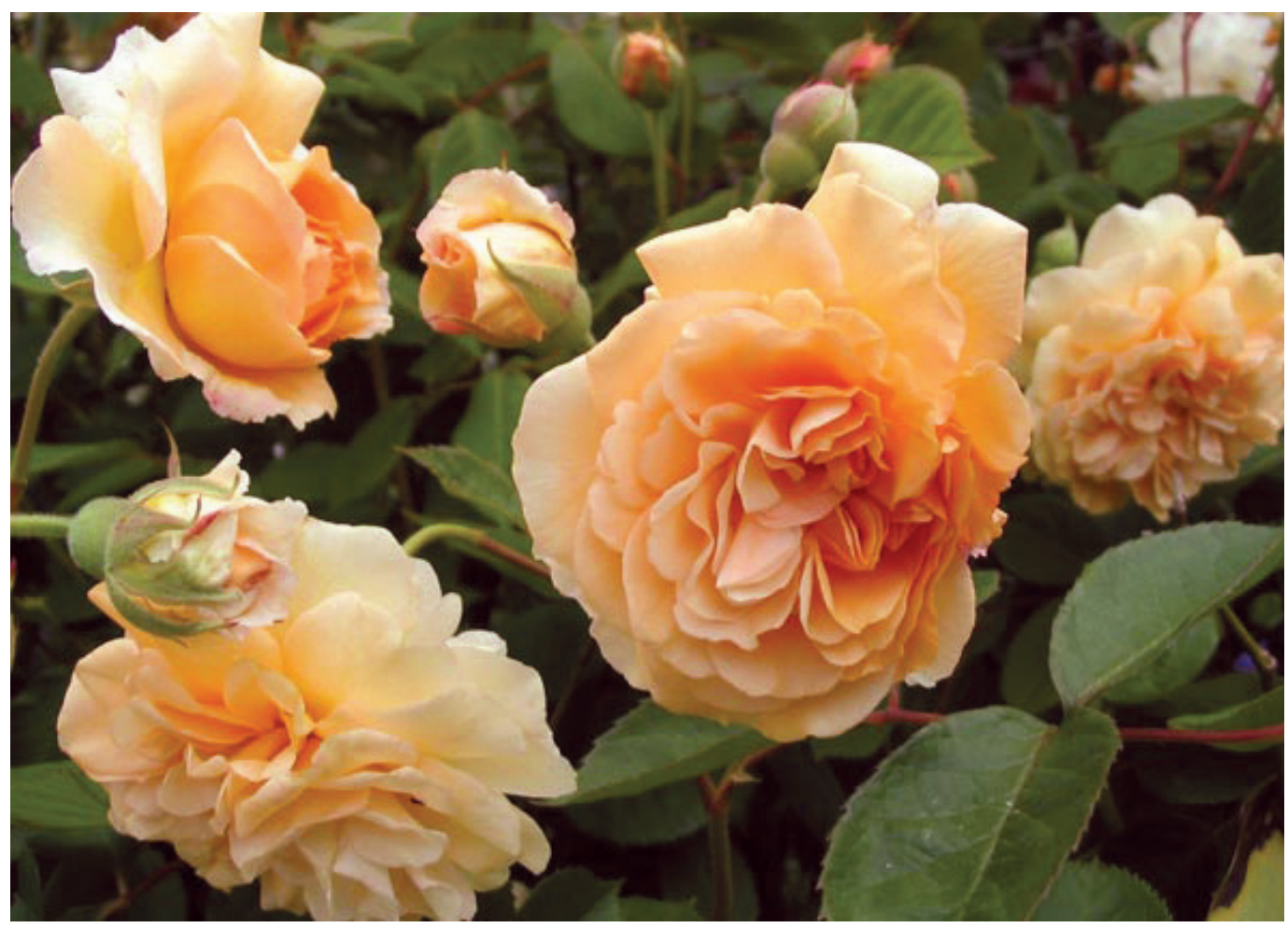

Figure 14: Moosey's Country Garden, Buff Beauty Rose Flower, 2010. Flowers themselves do not have a specific meaning, but when giving them the people in different circumstances, they can turn into a symbol of love, congratulations, or sorrow.

\section{NATURE'S PATTERNS, OUR PERCEPTIONS, \& CONNECTION WITH GRAPHIC DESIGN}

The next part of the paper explains the phenomena of patterns appearing in nature and humans' perception of them, and explores their aesthetic and analytical aspects, according to the three big groups of patterns that appear in nature. It links them to the usage in graphic design, presented with selected case studies. "Pattern awareness allows us as designers to choose the most appropriate relationships, which in turn lead the viewer effortlessly toward comprehension"(Macnab, 2008, p. 10). By the right interpretation of a certain pattern, we can, with its inclusion into a designed piece, embrace " the energy of its essence" and convey the message meaningfully and understandably (Macnab, 2012, p. 112). 


\subsection{PATTERNS - AN INTEGRAL PART OF OUR EXISTENCE}

According to Graham (2011), "patterns are an outward manifestation of an ordered structure and are clues as to how things are organized and connected."We are constantly tightly connected with patterns. When hearing the word pattern, most people probably think about the visual decorations on our clothes, walls, furniture, and other surfaces (Fig. 15). Patterns are much more than that. Not only do they decorate the objects surrounding us, they also exist within our bodies and in nature around us.

Patterns are so an integral part of everything that is. They form a complex web of interrelations and never stands alone. In our bodies, DNA is formed into the double helix (Fig. 16), the beat of the heart is making a constant repetition, and fingerprints are created by the visual patterns of convoluted lines (Fig. 17). There are also patterns, which dictate our behaviour and mental processes. We can see that they have a physical structure or are manifested through a process. Because of their usefulness, man has adopted them into the manufactured, human-made environment, for example, road systems or street positioning (Fig. 18), or has created his own patterns of repetition through time, to keep things in order and flowing, including traffic lights, predicted intervals of public transport arriving to stations, and more. According to Root-Bernstein and Root-Bernstein (2011), "people are, in fact, pattern-recognizing and pattern-forming creatures."
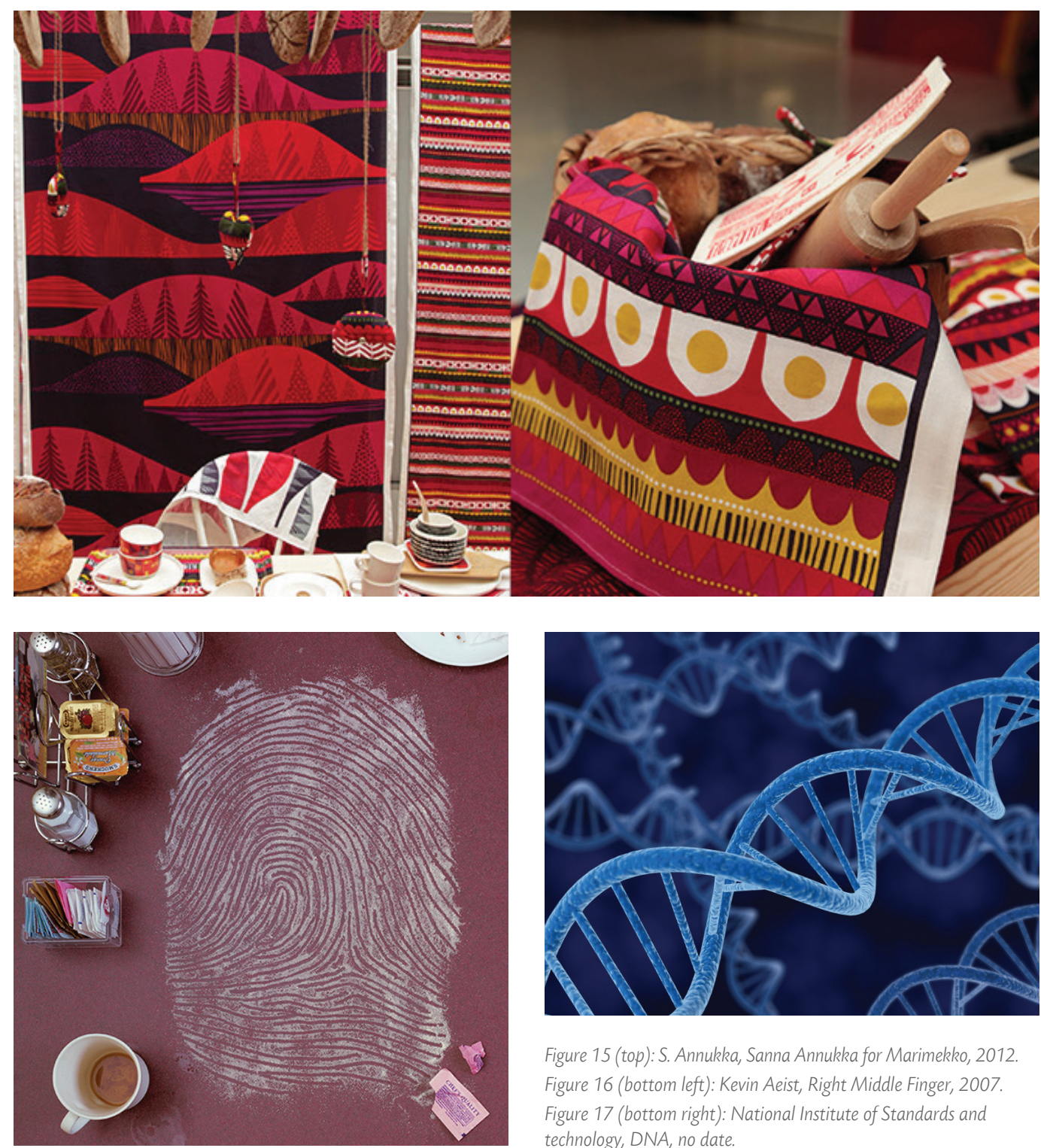

Figure 15 (top): S. Annukka, Sanna Annukka for Marimekko, 2012 Figure 16 (bottom left): Kevin Aeist, Right Middle Finger, 2007. Figure 17 (bottom right): National Institute of Standards and technology, DNA, no date. 


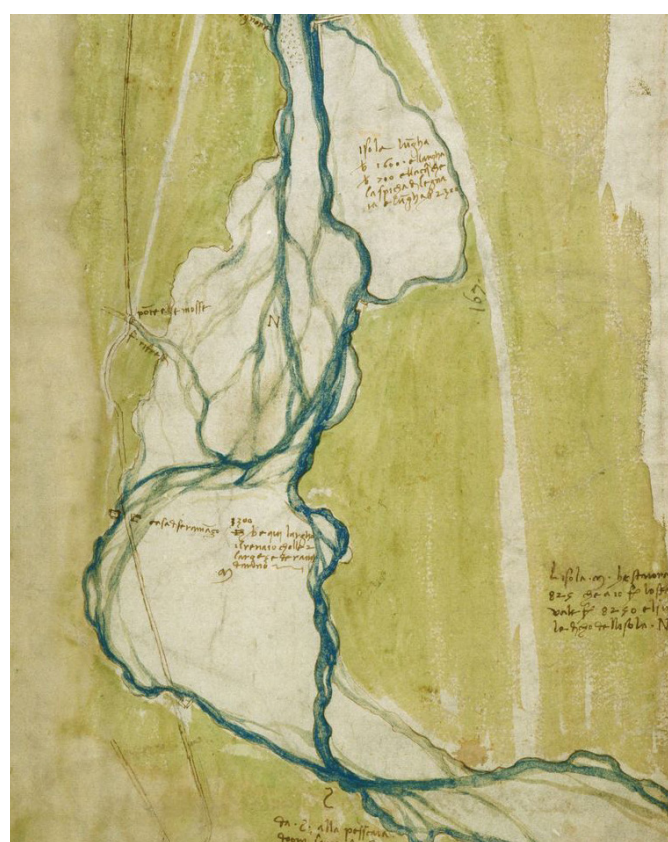

Figure 25a: Leonardo da Vinci, A map of the Arno west of Florence, 1504

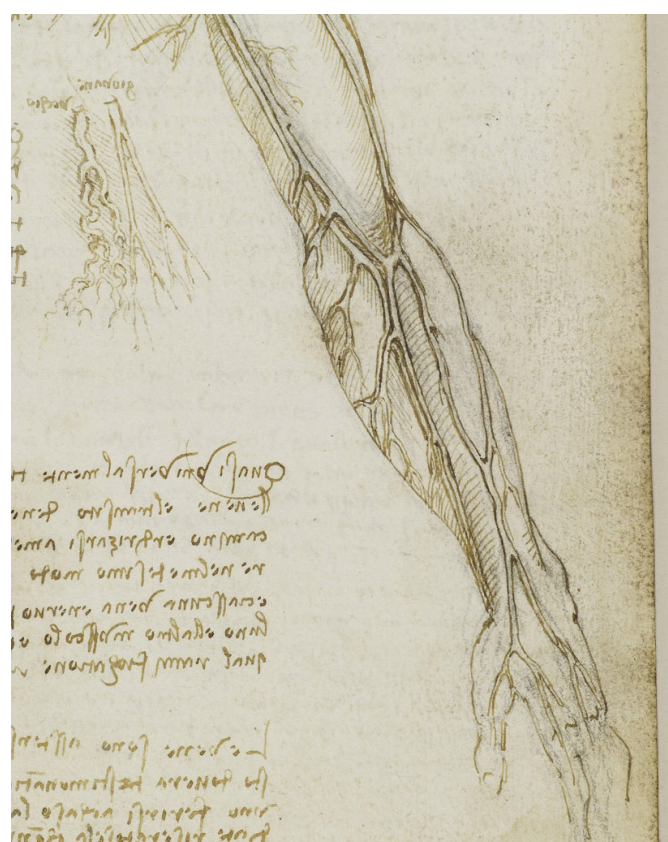

Figure 25b: Leonardo da Vinci, The veins if the Arm, 1508

\subsection{PATTERNS AND THEIR RELEVANCE TO GRAPHIC DESIGN}

How can the patterns from nature be relevant to graphic design? As mentioned before, visual communication transfers a certain message from a designer to a viewer. The latter interprets the message in his own way, and because of this, it is important that a designer visually transforms the energy of what is being communicated (Figs. 26-28), and according to Macnab (2012, p. 114), creates "a reciprocal understanding, leading to a relationship with a viewer". When a designed piece embodies what we intuitively sense, effective communication is created. Because patterns of nature reflect relationships and interactions that we are all instinctively familiar with, their implementation into design can create a solid way of communicating. We ' know' it because it is stored in our collective unconscious that 'has been accumulated by our ancestors over millennia through their experiences of living" (Macnab, 2012, p. 111).
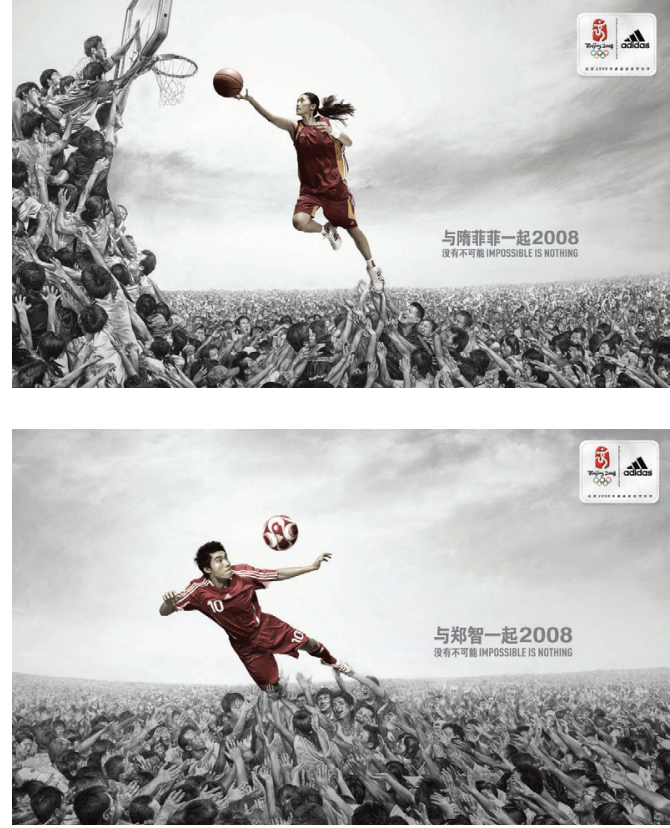

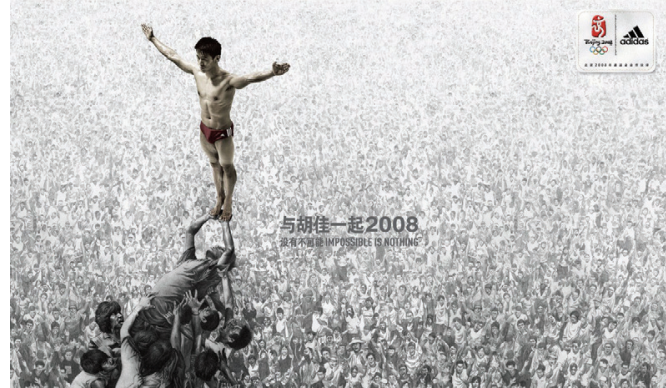

Figure 26 - 28: 180 TBWA, China, Impossible is Nothing - Adidas Campaign, 2008

Designers managed to visually transform the energy of communication - expectation and team spirit among sportsmen and audience. 


\subsection{INTUITIVE PERCEPTION OF PATTERNS}

When a pattern of intuitive experience is adopted in visual communication, our ability of making the meaning by deciphering and understanding it takes place (Macnab, 2008, p. 7). From observing and tracking nature's cycles, according to Macnab (2008, pp. 7-8), man learned how to interpret patterns and how to survive. By tracking the changes of seasons in a year, he realised how to secure himself against cold winters; through the observation of animals' migratory patterns, he conceived how to hunt them; he followed plants' growing cycles and this evolved into farming, and so on. "In order to make sense of the world, we look for repeating qualities in phenomena around us; we try to discern the reasons behind repeating events and processes" (Root-Bernstein and Root-Bernstein, 2011). According to Root-Bernstein and Root-Bernstein (2011), we are looking for a connection among things by shapes, colours, textures, numbers, and we are classifying them within the categories of our senses or according to the function or purpose (Fig. 29).

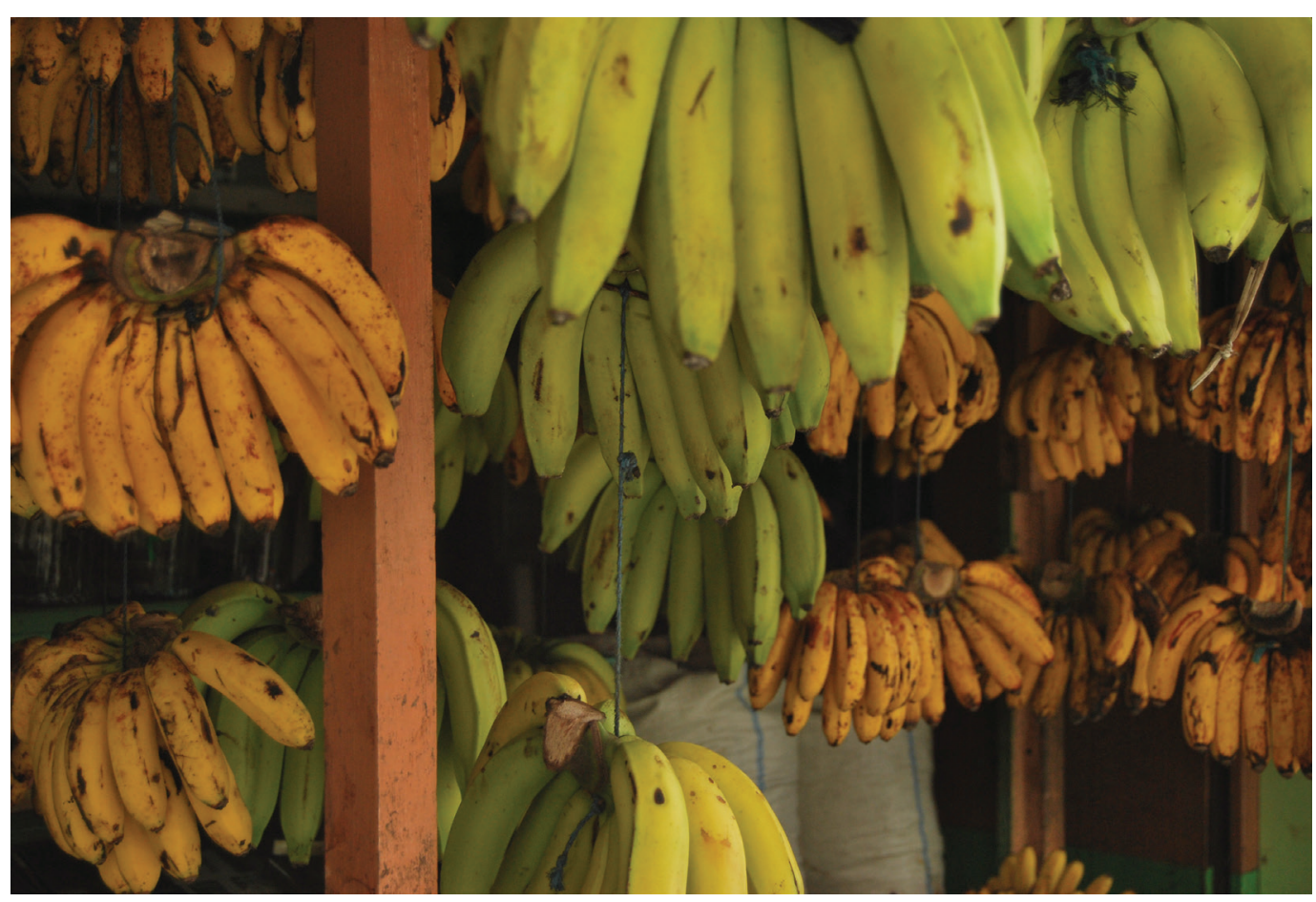

Figure 29: Maruša Račič, Bananas - Connections of Shapes, Colours and Numbers, 2009

\subsection{AESTHETICS OF PATTERNS AND BY-PRODUCT HYPOTHESIS}

Hekkert (2006, p. 157) in his article reports how evolutionary psychology manages to realise that we find patterns deriving from our environment aesthetically pleasing with the "by-product" hypothesis. This hypothesis explains where our aesthetic pleasure, common to our different senses, derives from. The core of it is our tendency, and so our notion for adaptation. Throughout evolution, humans have faced different problems that threatened their survival; for example, finding a mate or nutritious food. It is explained as follows (Leder et al., 2004, cited in Hekkert, 2006, p. 161):

Through a slow process of natural selection, psychological mechanisms have evolved that are perfectly fit to solve these problems. These human design features are called adaptations. ... In other words, it must be beneficial for humans to seek cues or patterns that serve these adaptive functions. We therefore (have come to) derive (aesthetic) pleasure from patterns or features that are advantageous to these functions. 
The function of our visual system can help us understand why we find certain visual features aesthetically pleasing (Leder et al., 2004, cited in Hekkert, 2006, p. 162).

Our sight informs us about our environment; it helps us by detecting different obstacles and estimating distances to navigate around easily, and allows us to identify things (Fig. 30). According to Leder et al. (2004, cited in Hekkert, 2006, p. 163):

We can thus predict that we like to look at things that support navigation and identification. These things are patterns in the environment that facilitate perceptual organisation,... These patterns make us see relationships and differences, they make us see that certain things belong together whereas others are unrelated, and they help us to make a most likely and economically efficient interpretation of the world out there.

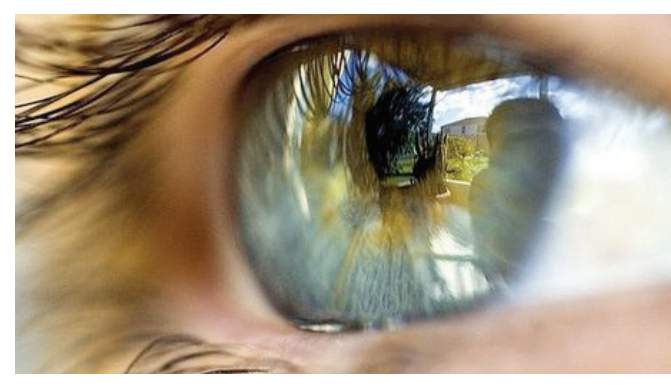

Figure 30: Erion Cuko, Sight, 2011

\subsection{THREE ASPECTS OF PERCEIVING NATURE'S PATTERNS}

Graham (2011) emphasises the holistic approach that we need to take when considering nature's patterns. There are three interdependent aspects from which a pattern can be observed, aesthetic, spiritual, and analytical. The first two aspects are processed on the right side of the brain, which is responsible for creative, intuitive, and more perceptual critical thinking. But at the same time, the left hemisphere is engaged in the perception of a pattern as well. As this is a logical part of the brain, it is dealing with the third aspect, the analytical; we are trying to realise the logic (physical laws and the on-going processes) behind our cognition (Graham, 2011).

\section{COMPONENTS OF PATTERNS AND ENERGY TRANSFORMATION}

\subsection{PATTERNS' COMPONENTS}

To understand why different groups of patterns appear and exist in nature, we must look at the components that form the unity of a pattern. Each pattern exists within the frame of a form (the pattern's look or architecture), context (environment), and function (dynamics of a pattern) that cannot be separated.

The following practical example from nature illustrates this connection (Graham, 2011):

In the flow of rivers, the source is a branching structure connecting to a central and larger flow of water. Here, the shape of the land (a context called geomorphology) provides a structural template (form) that shapes the flow of water. But, then the river path in the terrain becomes shaped by the dynamic flow (function) of water and other ecological processes. Form and function become interrelated. Through the interplay of form and function, a pattern in nature is formed (Graham, 2011). 


\subsection{TRANSFORMATION OF ENERGY}

Before focusing on the three big groups of patterns appearing in nature and their meanings, the aspect of energy transformation that occurs within the patterns needs to be emphasised. According to Macnab (2012, p. 42), each pattern, with its dynamic processes, is basically transforming, moving, storing, or connecting, energy. Bejan and Zane (2012, pp. 7-10) argues this in a broader context from a slightly different perspective when explaining the flow of the systems. Everything that exists is possible because of flow. One flow system in our bodies is the blood circulation in our veins. Everyday, we are part of traffic flows. The products that we buy have flowed from factories to shops. There are other countless examples. To keep the process of flowing constant, energy is needed to make it possible. Here, we can draw parallels with the energetic principles of patterns; they would not exist without the component of energy, because without it, flow could not be created and would not build them. There are three major groups of patterns in nature, based on energetic principles that are related to "specific universal principles"(Macnab, 2008, p. 15). These are patterns of movement, patterns of connectivity, and patterns that stack and pack.

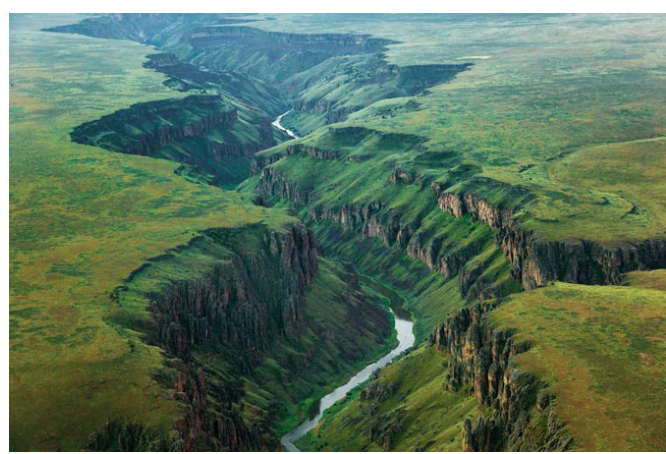

Figure 31: Michael Melford, Owyhee River, no date.

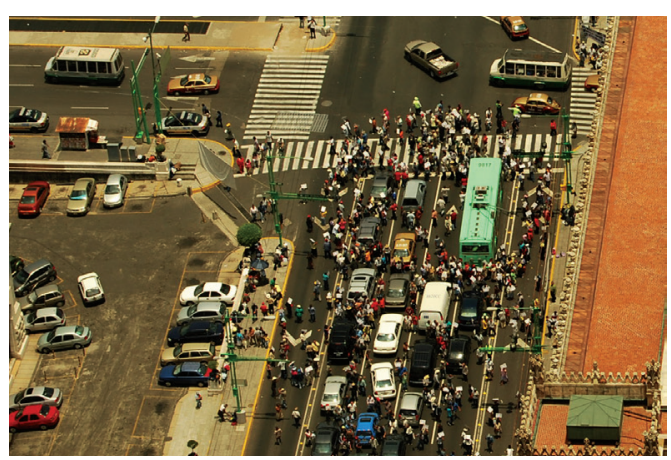

Figure 32: Maruša Račič, Traffic Flow, 2010.

\section{PATTERNS OF MOVEMENT}

\subsection{BRANCHING AND MEANDERING PATTERNS}

The first big group, patterns of movement, are tasked to transport energy from one place to another. They can be divided to branching and meandering patterns. The difference is that the first are transforming the energy more directly, with constant force and speed and impulsively, while the movement within meanders is relaxed and wandering (Macnab, 2012, p. 115). Branching patterns are basically a subcategory of fractals (Fig. 33), the self-similar structures or objects that form complex patterns. If any small part of a fractal object is taken and magnified, it will still have the similar structure as the whole object on every level of magnification (Novak, 2004, p. 177).

Branching patterns can be found everywhere where movement occurs; in our bodies, which are actually built as a fractal structure, the vein system is branched to move blood to organs (Fig. 34), tubes in the lungs split into smaller tubes (Fig. 35), and their presence in nature can be seen in tree branching, leaf vein structure, waterfalls, crystals of snowflakes, on the scale of the surface of Earth and more (Figs. 36-41). These patterns are also forms in our manufactured environment, such as road and street systems (Fig. 42) or systems of water and electricity supply. They usually have an angular structure that helps to transfer the energy more immediately. With the pattern of branching, we can so visualise the messages that are carrying the idea of movement, efficiency, direct intention, and hierarchical structure (Macnab, 2012, pp. 115-116). 


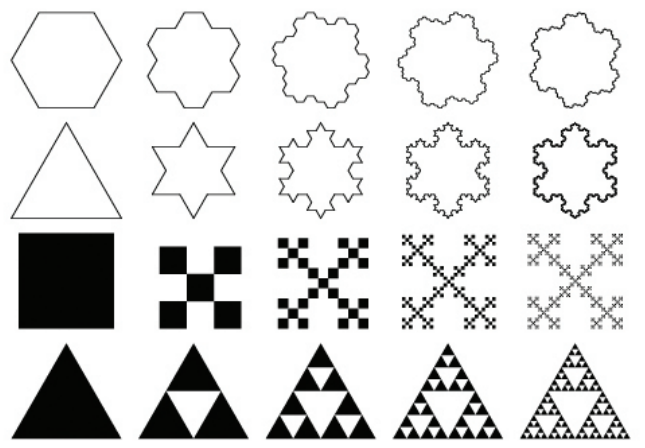

Figure 33: MathWorld, Fractals and Self-similarity, no date
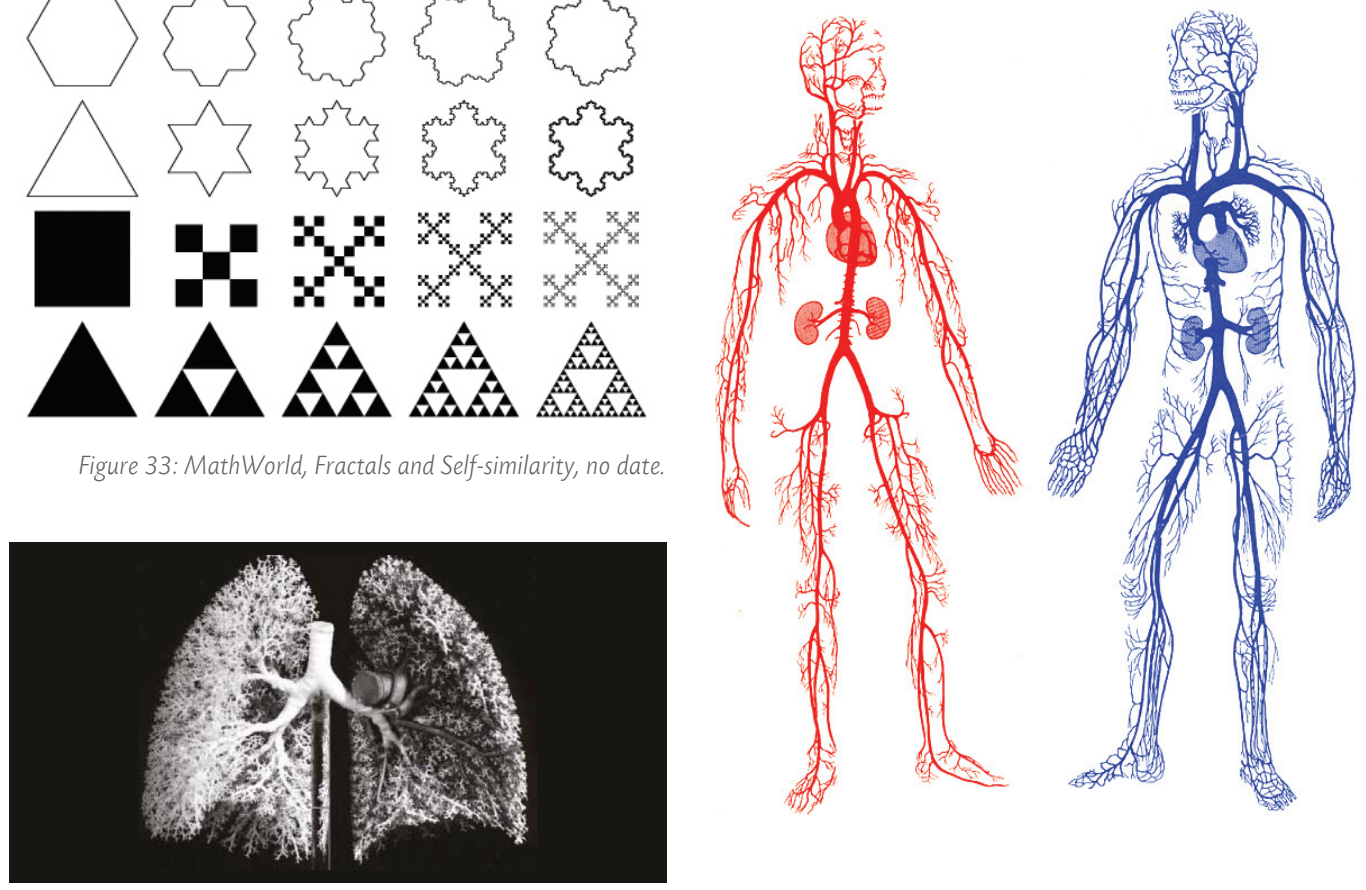

Figure 35: Anatomical Institute Bern, Human Lungs, no date. Figure 34: Access Excellence Classic Collection Arterial and Venous Systems, no date.
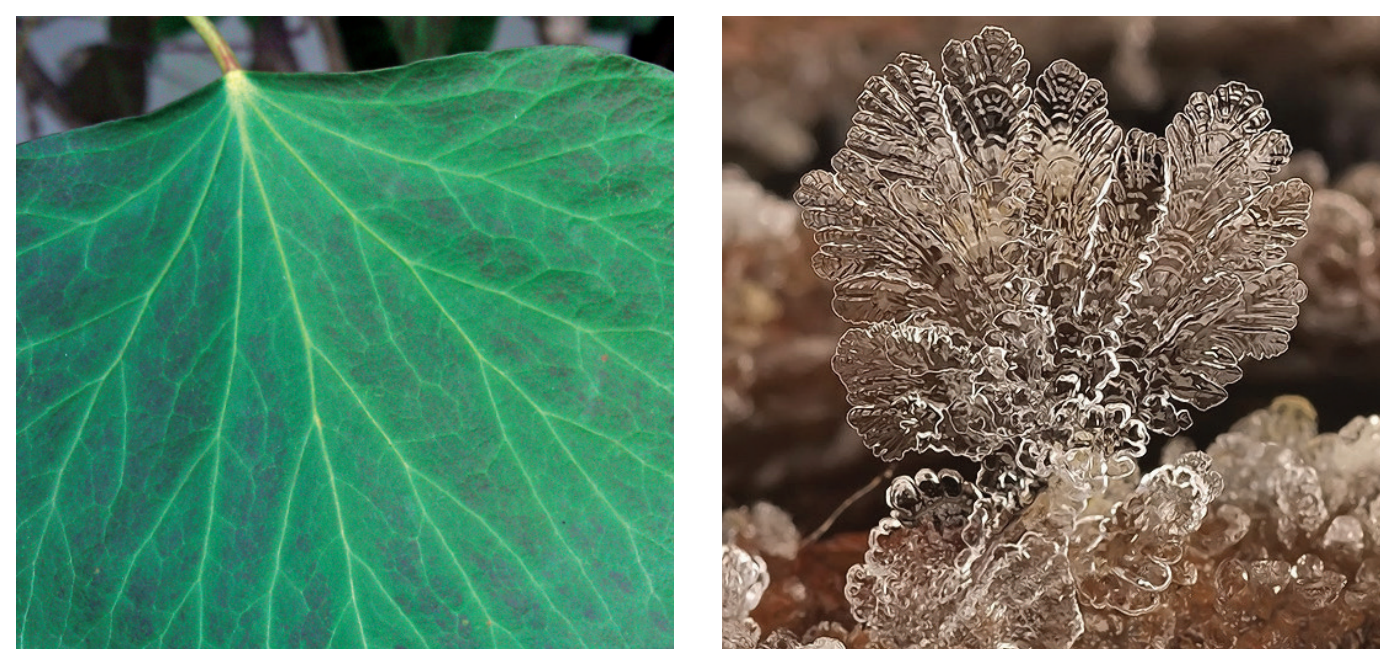

Figure 36: Helena Jakoube, A Leaf, 2013

Figure 37: Andrey Osokin, Snow Crystal, 2013.
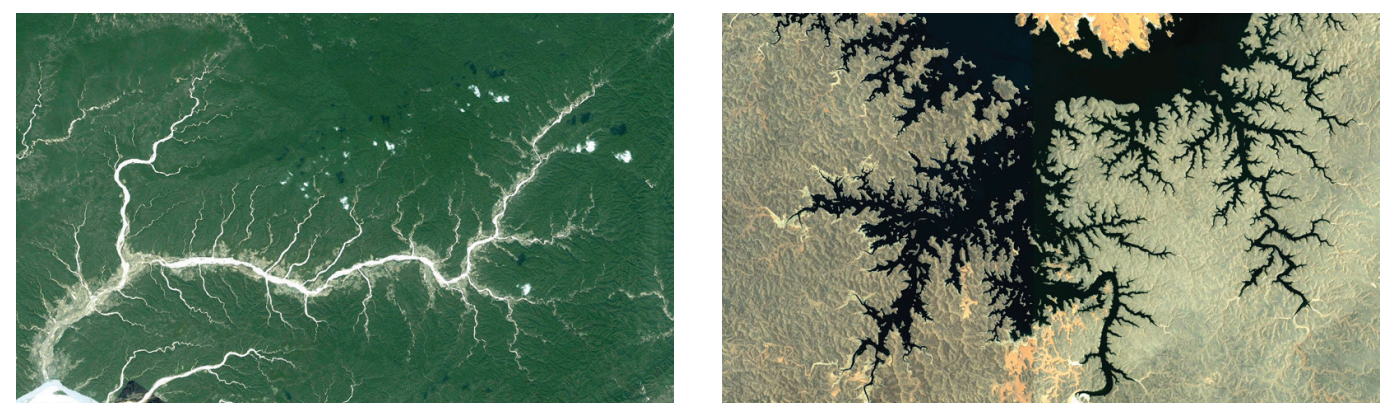

Figure 38 - 39: Google Earth, Fractals on Earth - Burma and Egypt, 2010 - 2012. 

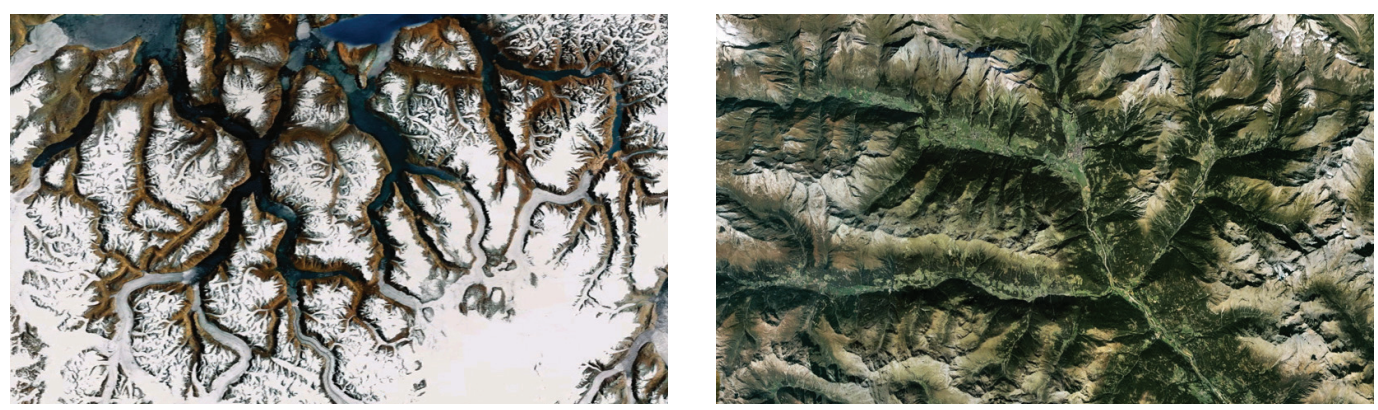

Figure 40 - 41: Google Earth, Fractals on Earth - Greenland and Austria, 2010 - 2012

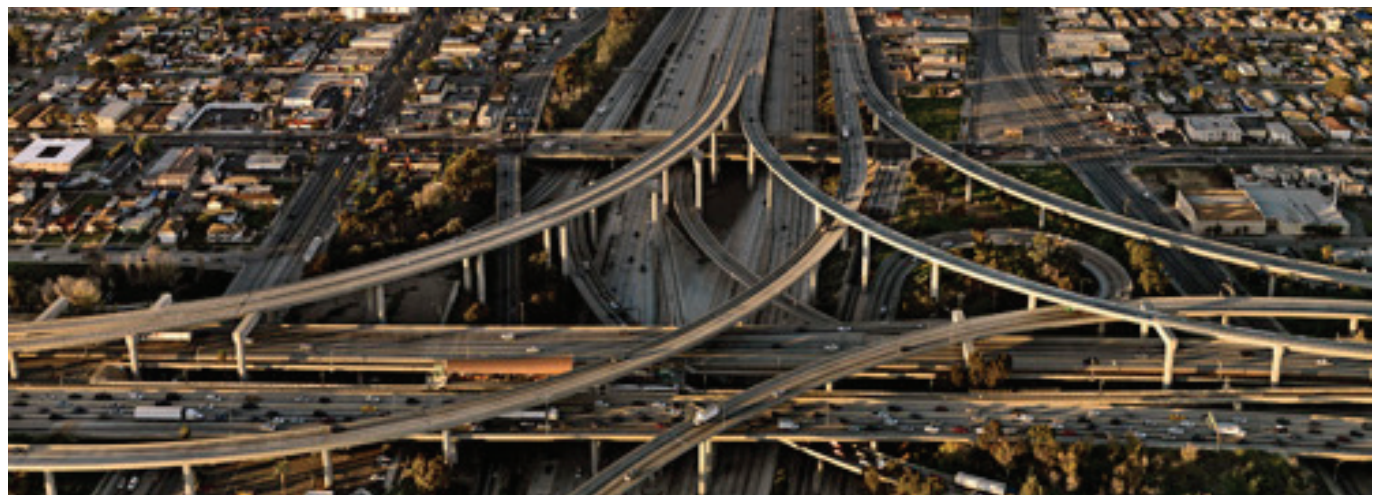

Figure 42: Edward Burtynsky, Highway \#1, 2013.

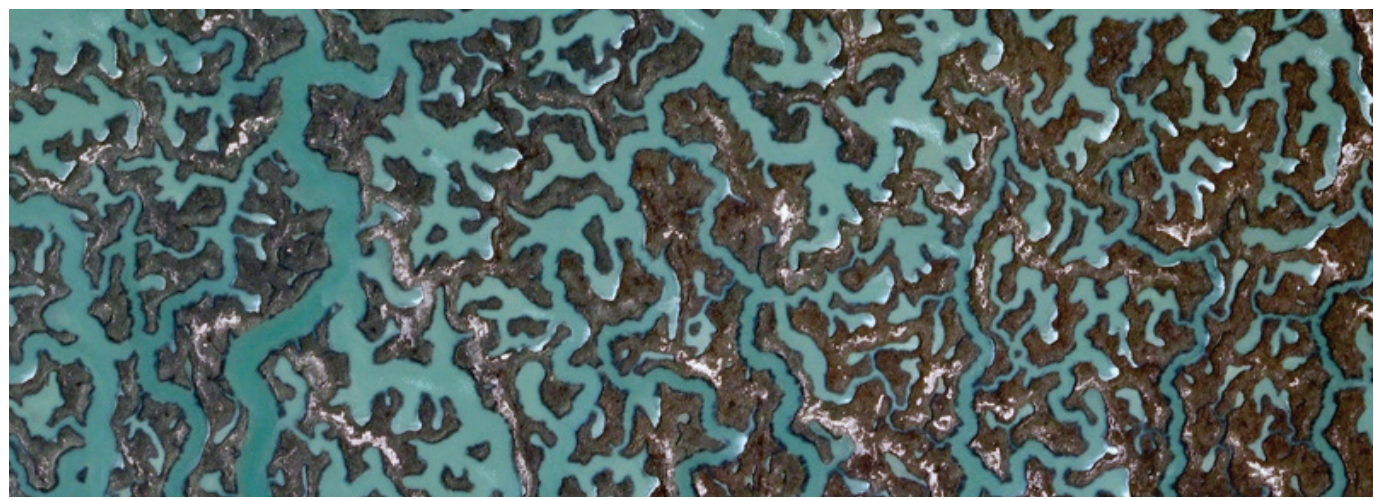

Figure 43: Google Earth, Fractals on Earth - Spain, 2011.

Opposed to this, meandering patterns are distributing energy in a circuitous path, and so at a more constant pace (Fig. 43). It is interesting that the term meander is basically derived from nature. The word is based on the Greek name of a river in present-day Turkey, which was called Maiandros. The term was afterwards used for everything convoluted and winding (Harper, 2012). Some rivers and clouds are great examples of meandering in nature (Fig. 44). The shape and movement of snakes is meandering, and in our bodies, the pattern is present in the brain convolutions and digestive system (Figs. 44-46). Meanders are broadly adopted in art (meandering patterns were already popular in Greek art and culture), especially in the form of labyrinths, which are the metaphor for a journey to our personal centre and a symbol of a life journey (The Labyrinth: Walking Your Spiritual Journey, 2012). These patterns can be appropriate for communicating the idea of connectivity and interactivity of different sources or people. The following case studies depict the connection of the patterns of movement with graphic design, and explain the way they communicate in these particular examples. 


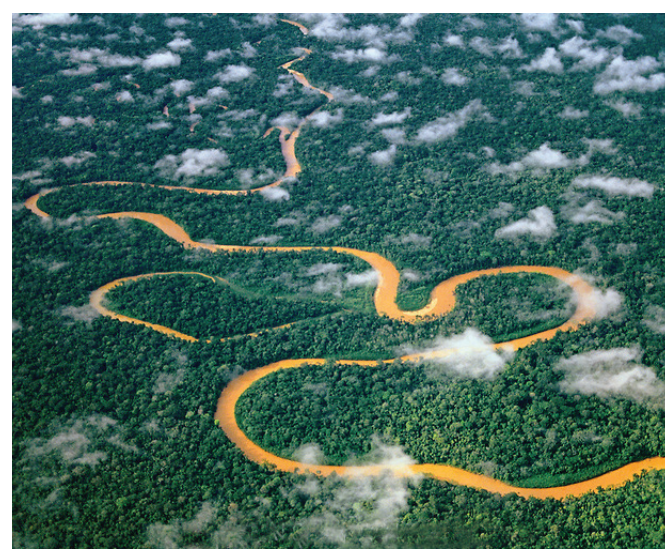

Figure 44: Frans Lanting, Meandering River, Manu National Park, Peru, no date.

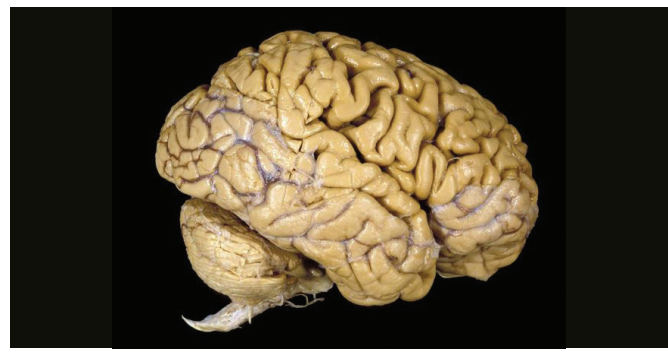

Figure 46: Fred Hossler, Human Brain, no date.

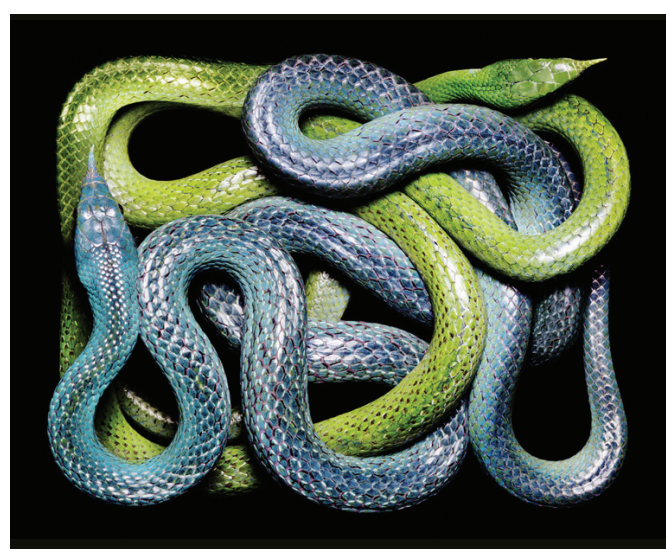

Figure 45: Guido Mocafico, Rhynchophis Boulengeri, 2003
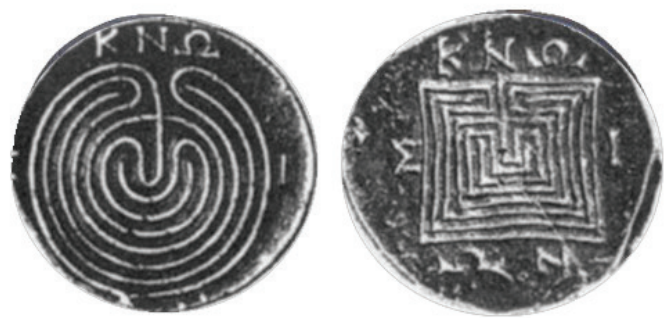

Figure 47 (right): Greek Coins, Cretan Coin The Minotaur's Labyrinth, 67 BC.

\subsection{SHAHAL TELEMEDICINE LOGO - BRANCHING PATTERN IN LOGO DESIGN}

This logo, depicted in Figures 48-51, was one of the winners of WOLDA 2008 (The Worldwide Logo Design Annual), and was created for Shahal Telemedicine (WOLDA, 2012). "Telemedicine can be broadly defined as the use of telecommunication in an organized system to provide medical information and health care"(SHL Telemedicine, 2012). The company's logo is using the principles of the branching pattern; it is stretching out from the core, like the service stands in the centre and creates the network with its patients. One can also perceive the feeling of growth, which might intuitively show the company's ability to include new patients into their system. The service's intention of quick interaction with patients and efficient help (which is connected with short reaction time) matches the message of the branching pattern, so this logo successfully communicates the service's philosophy with the intuitive message of the pattern.
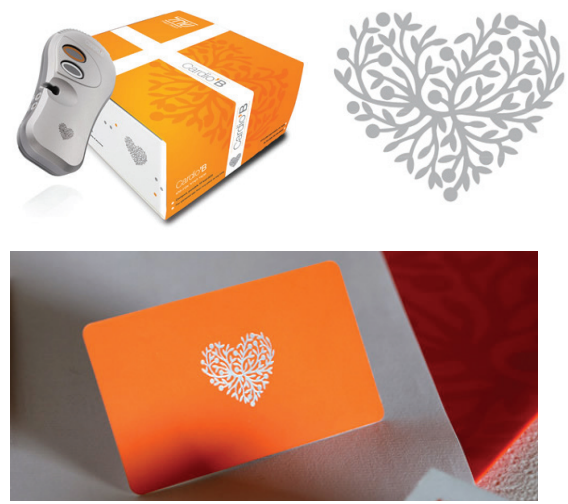

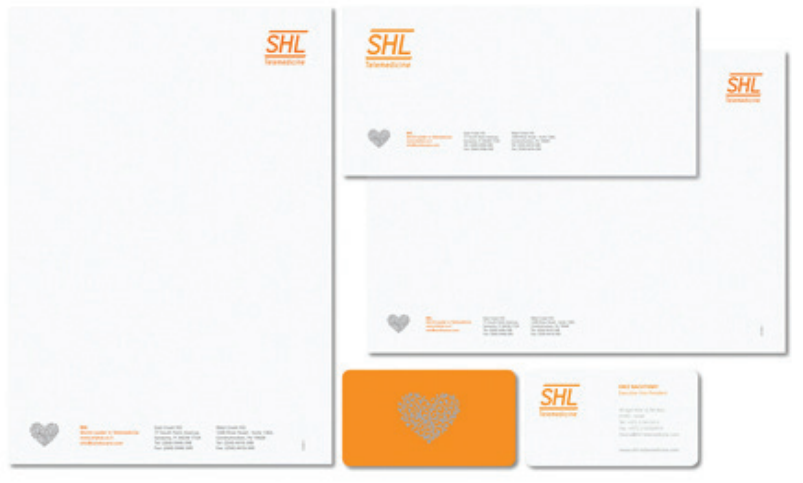

Figure 48 - 51: Dan Alexander er Co., Shahal Telemedicine Identity, 2005. 


\subsection{SUZUKI BRAND IDENTITY - IDENTITY GUIDELINES INSPIRED BY BRANCHING SNOW CRYSTALS}

This example (Fig. 52) depicts how the designer Sven Voelker compared the creation of Suzuki's new corporate design with snow crystals, which are based on fractal geometry. Instead of making a precise brand manual for a new identity that would define every single detail of it, designers laid down only some basic guidelines for the visual language (Voelker, 2012). According to him (Voelker, 2007), snow crystals are all based on a sixty-degree angle of growth and so look similar, but never exactly the same. On the way from the sky to the Earth, they are continuously changing their shape and structure. Voelker's design team did the same thing with their design. They created only a few defined rules about the identity, and stated that a similar visual language should be spoken, but there is also enough space left for unique and distinctive stationery that can grow over time. Besides taking inspiration from nature to create the guidelines that allow limited but flexible design solutions, this example also nicely balances the highly technological car industry with the elements of nature.

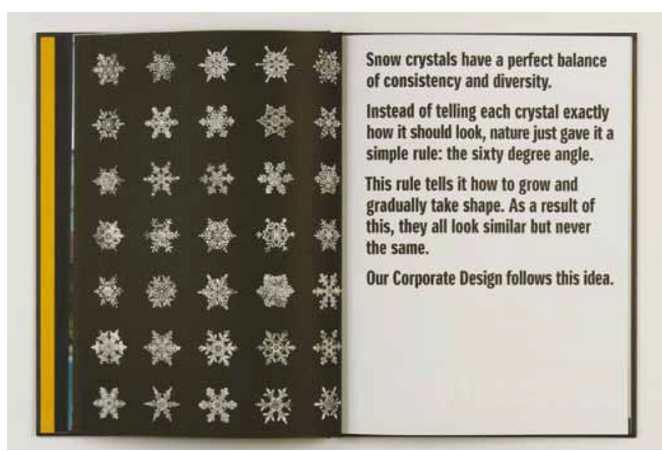

Figure 52: Sven Voelker, Suzuki Brand Manual, 2012

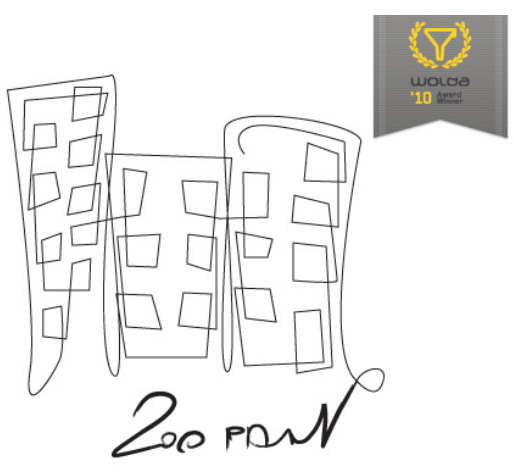

Figure 53: Peek-a-boo, Micham 200, 2010

\subsection{MITCHAM 200 - A LOGO WITH MEANDERING FORM}

Mitcham is a small neighbourhood in Hod Hasharon, a city in Israel. "A group of about 10 of the neighborhood's residents got together with the aim of dealing with the neighborhood's needs and services, such as infrastructure, education and culture" (Materia, 2011). The logo (Fig. 53), another winner of WOLDA 2010, created from the Peek-A-Boo design company, is formed as an intersected line that can visually present the idea of "unification and freedom of action"with no hierarchical structure (WOLDA, 2012).

\section{PATTERNS OF CONNECTIVITY}

\subsection{SPIRALS AND HELICES}

The next group of nature's patterns are patterns of connectivity that can be divided into spirals and helices. Spirals are some of the most versatile patterns and represent regeneration and eternity, the act of creativity and growth, an integral part to the physical world and on symbolic level, the idea of human spiritual growth (Ward, 2006, p. 12). By definition (Oxford Dictionaries, 2013), a spiral is 'winding in a continuous and gradually widening (or tightening) curve, either around a central point on a flat plane or about an axis so as to form a cone". Its sister, the helix, differentiates itself in a way that it expands not continually outward like spirals, but is always with the same diameter (Macnab, 2012, p. 125). Spirals occur in nature over and over again, stretching from micro to macro levels of our existence. All complex organisms' embryos at the beginning display a spiralling shape, growing out from its centre (Fig. 53). Numerous animals swirl their different parts - an octopus' arms, a snakes' body, a snail's shell, and an elephant's trunk (Fig. 54). In our bodies, spirals appear inside our ears (Fig. 55), on our fingertips, and are woven into DNA. Our blood flows in spiral waves, too. 
The pattern is also widely present among plants, in rose petals, as plant tendrils, in the position of seeds in a sunflower (Fig. 56), and more. The waves of the sea, clouds, and hurricanes' winds swirl, and above it all, galactic spirals (Fig. 57) stretch through our universe (Ward, 2006, p. 14). Macnab (2008, p. 17) claims, 'this is one of the most powerful patterns to human perception because it is so directly related to our own existence."In our cultures, we adopted spiral pattern in architecture, as staircases or different ornaments, as different representative models like one showing 'the development of cultures through a rising, widening spiral of increasing complexity" (Buchanan, 2012) and also as the perception of time; it can be described as linear, cyclical, and also as spiral.

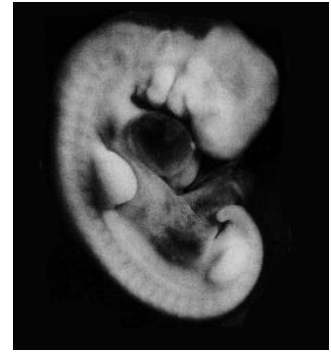

Figure 54: Developmental Stage in Human Embryo, 1956.

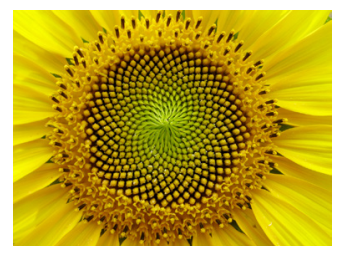

Figure 56: Lucapost, Sunflower: The Fibonacci Sequence 2007.

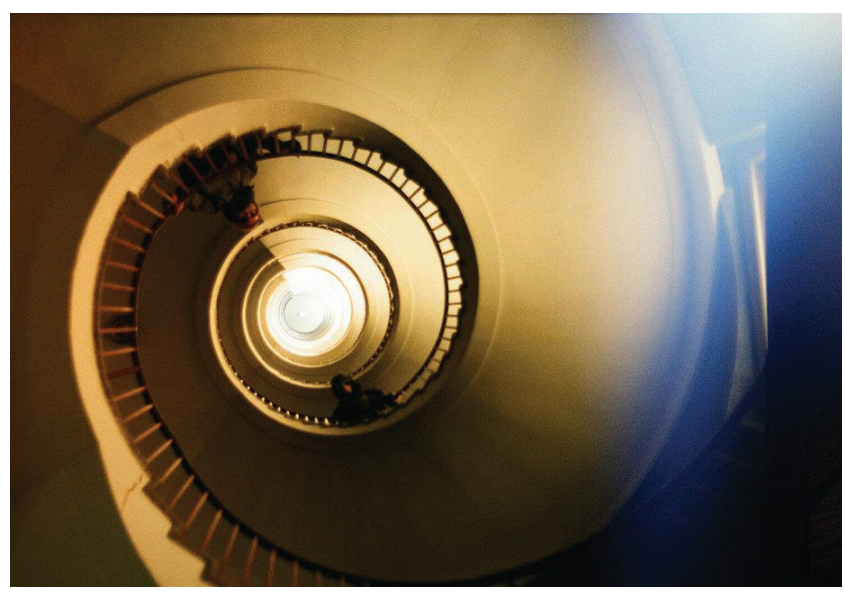

Figure 58: Daniel Plavecky, Going Up, 2012.

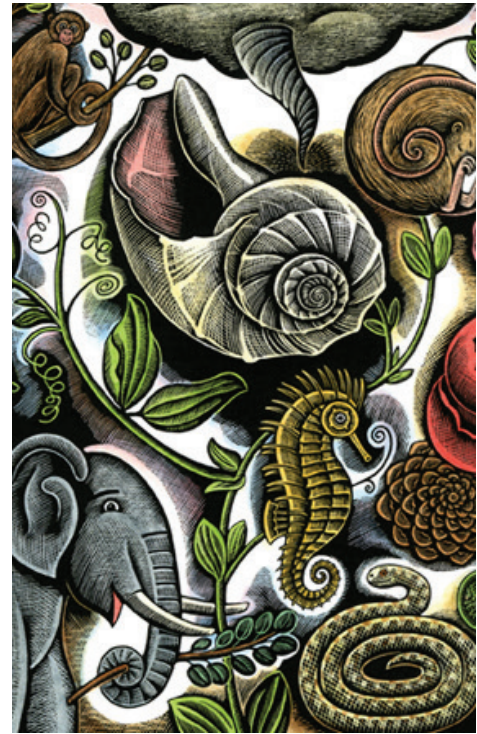

Figure 55: Beth Krommes, Swirl by Swirl, 2011. Team, Spiral Galaxy NGC 1376, 2010.

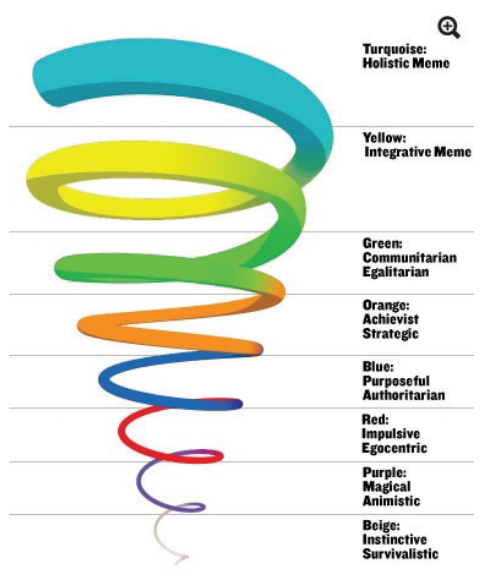

Figure 59: Don Edward Beck and Christopher C. Cowan, Spiral Dynamics, 1996.

Spirals in nature are formed in the geometric proportion of the Golden Ratio, also known as divine proportion (Figs. 60, 62). "The Golden Ratio is a term used to describe aesthetically pleasing proportioning within a piece" (Art History, 2013). We can demonstrate it with "dividing a line into two parts, one longer than the other, so that the whole line, compared to the longer part, is the same proportion as the longer part compared to the shorter"(Ward, 2006, p. 17). If we make a curved line on the squares that are proportionally decreasing, starting in the first square, continually going on to touch the far side of the second 
and so on, it results into creating a Fibonacci spiral (Ward, 2006, p. 18). The proportions were recognised as appealing and were widely used through the history of art and design (Figs. 63, 64). According to Livio (2003, p. 10), "in the long search for an elusive canon of ' perfect' proportion, one that would somehow automatically confer aesthetically pleasing qualities on all works of art, the Golden Ratio has proven to be the most enduring."

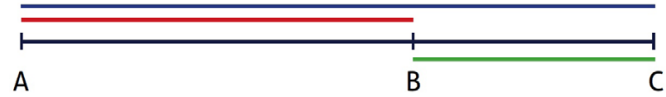

Figure 60: Maruša Račič, Divine Proportion, 2013

\section{The Golden Rectangle}

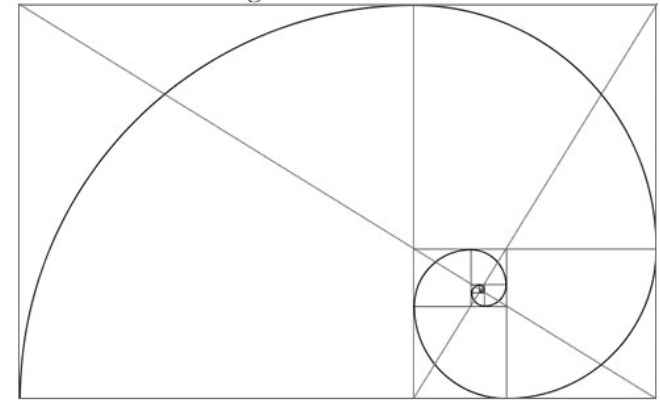

Figure 61: Kepler's Discovery, The Golden Rectangle, no date.

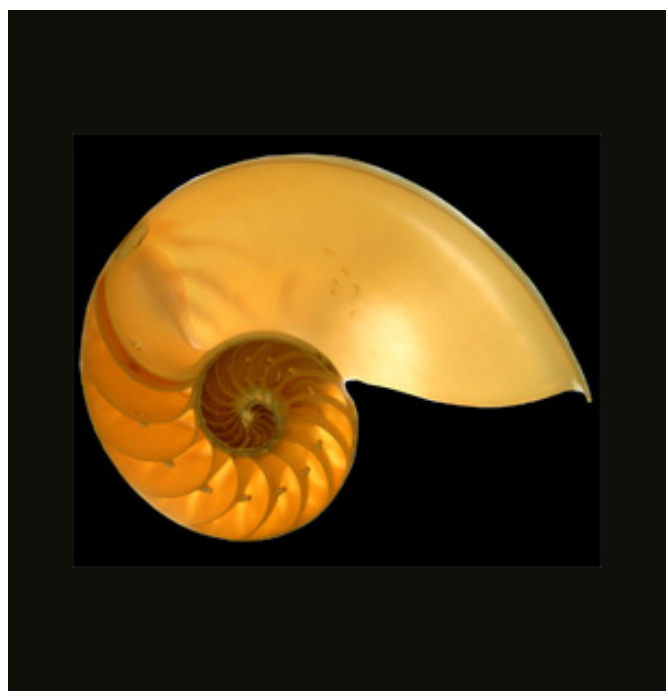

Figure 62: Peter Werner, Nautilus, no date.

With the inclusion of spiral patterns into visual communications, we can so express the ideas of growth and connectivity and enhance the aesthetic sense of our work with Golden Ratio proportions. The next few examples depict successful usage of spiralling patterns in graphic design.

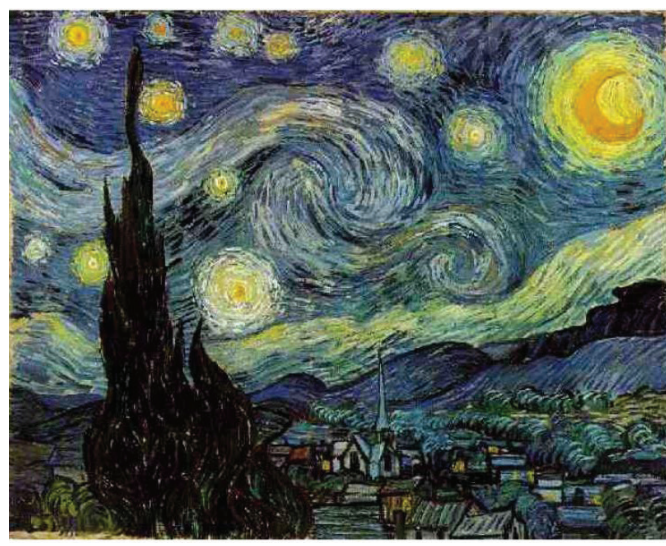

Figure 63: Vincent van Gogh, The Starry Night, 1889

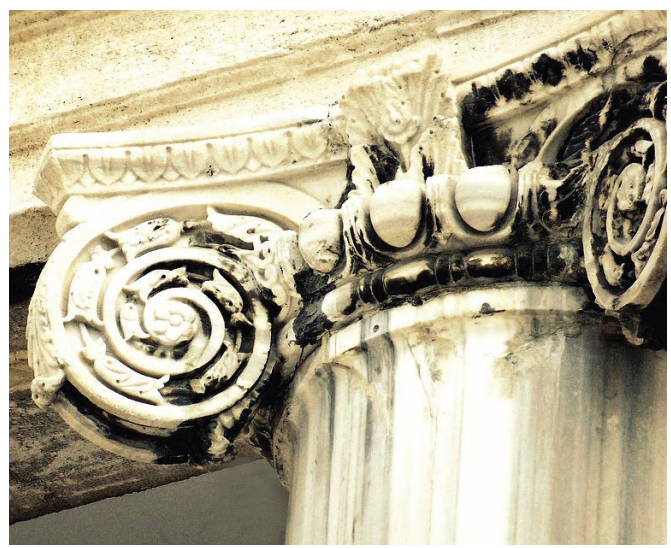

Figure 64: Rbnptrs, Column, 2009 


\subsection{SEED MEDIA GROUP CORPORATE IDENTITY}

This identity for the Seed Media Group, a scientific publisher of magazines, books, and films, was designed by the Sagmeister e $\mathrm{Walsh}$ design firm (Figs. 65-67). The intention of their design was to blend the fields of media and science into one identity (Sagmeister $e$ Walsh, 2012). They referred to nature and used a form of phyllotaxis; the term describes the arrangement of leaves in some plants that form two spirals directing in opposite directions and create a distinctive pattern in the Golden Ratio (Wolfram Mathworld, 2013). The designers of Sagmeister e Walsh (2012) claim that "we were looking for something open ended and flexible, a vessel we could fill with new meaning."The principle of the form allowed them to create a dynamic identity, where the logo in different contexts reflects the cultural surroundings. By changing its colours, different imagery is created.

The "Science is Culture"(Seed Media Group, 2012), says the motto of the group and the identity is reviving it, and with the pattern they managed to connect different aspects (science and media) to create a visually pleasing identity.
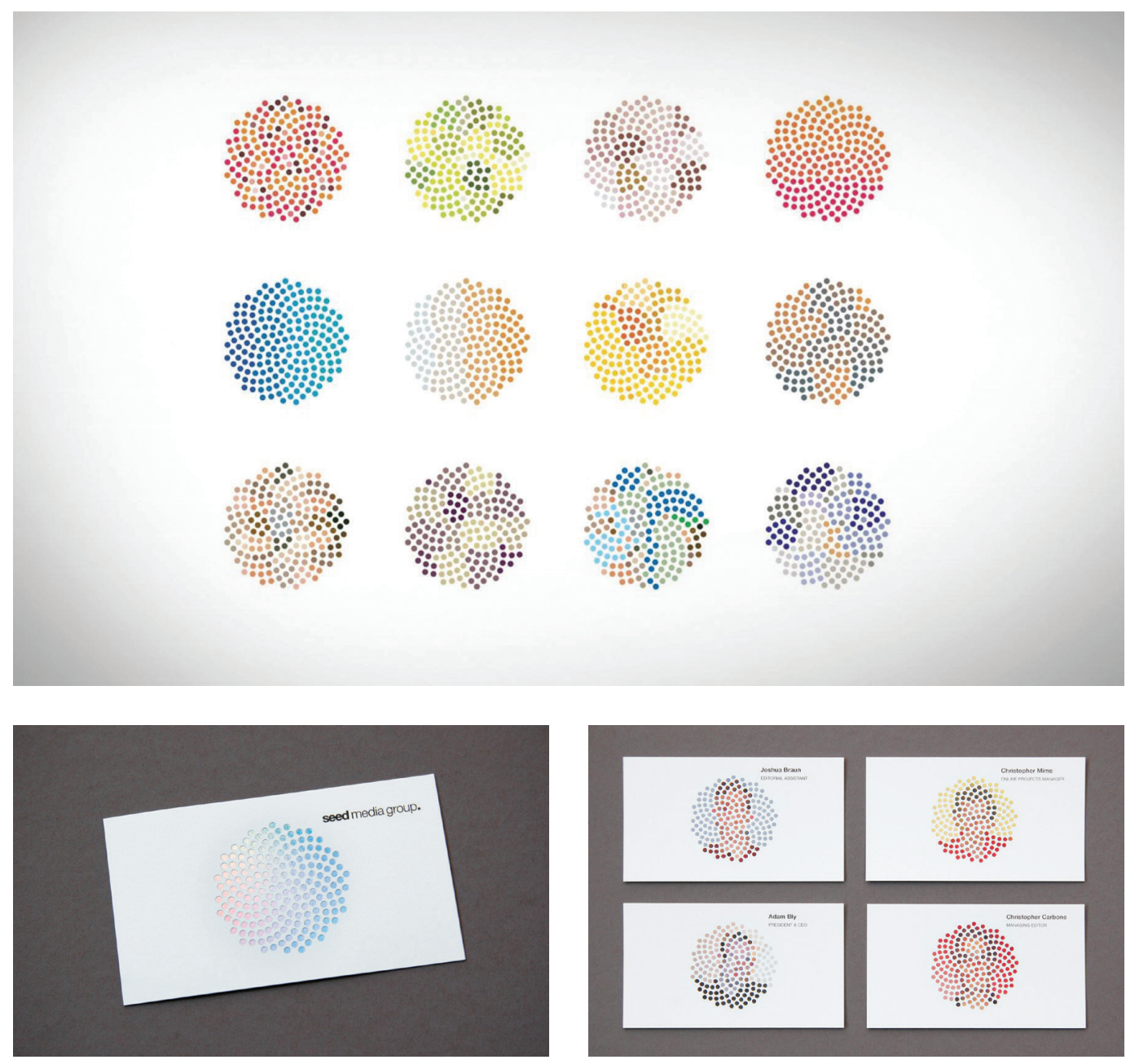

Figure 65 - 67: Sagmeister er Walsh, Seed Logo, 2005 


\subsection{MARIAN BANTJES}

Marian Bantjes is a renowned Canadian designer and illustrator. Her work strongly reflects organic, fluid elements, forming underlying structures from nature. Speaking for TED (Bantjes, 2010), she explains:

So I exist somewhat outside of the mainstream of design thinking. Where others might look at measurable results, I tend to be interested in more ethereal qualities, like: 'Does it bring joy? Is there a sense of wonder? Does it invoke curiosity?' ... So I have a particular imaginative approach to visual work. The things that interest me when I'm working are visual structure, surprise, and anything that requires figuring things out. So for this reason, I am particularly drawn to systems and patterns.

She has included swirling patterns in many of her works, for example the decorations of an article for Print magazine, encapsulating the connections of thoughts about the future of graphic design, predictions spoken some 50 years ago (Bantjes, 2012).
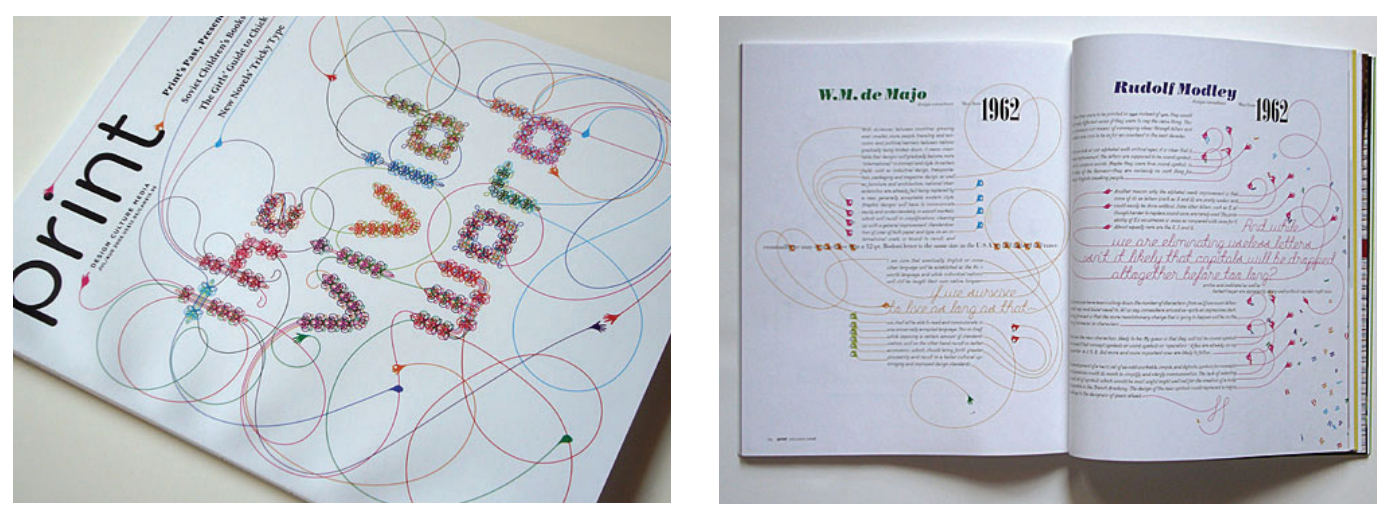

Figure 68 - 69: Marian Bantjes, Rint Magazine Jul/Aug, 2006

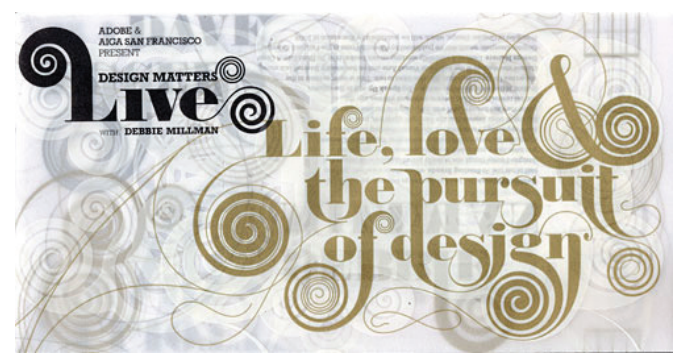

Figure 70: Marian Bantjes, Design Matters Live, 2007.
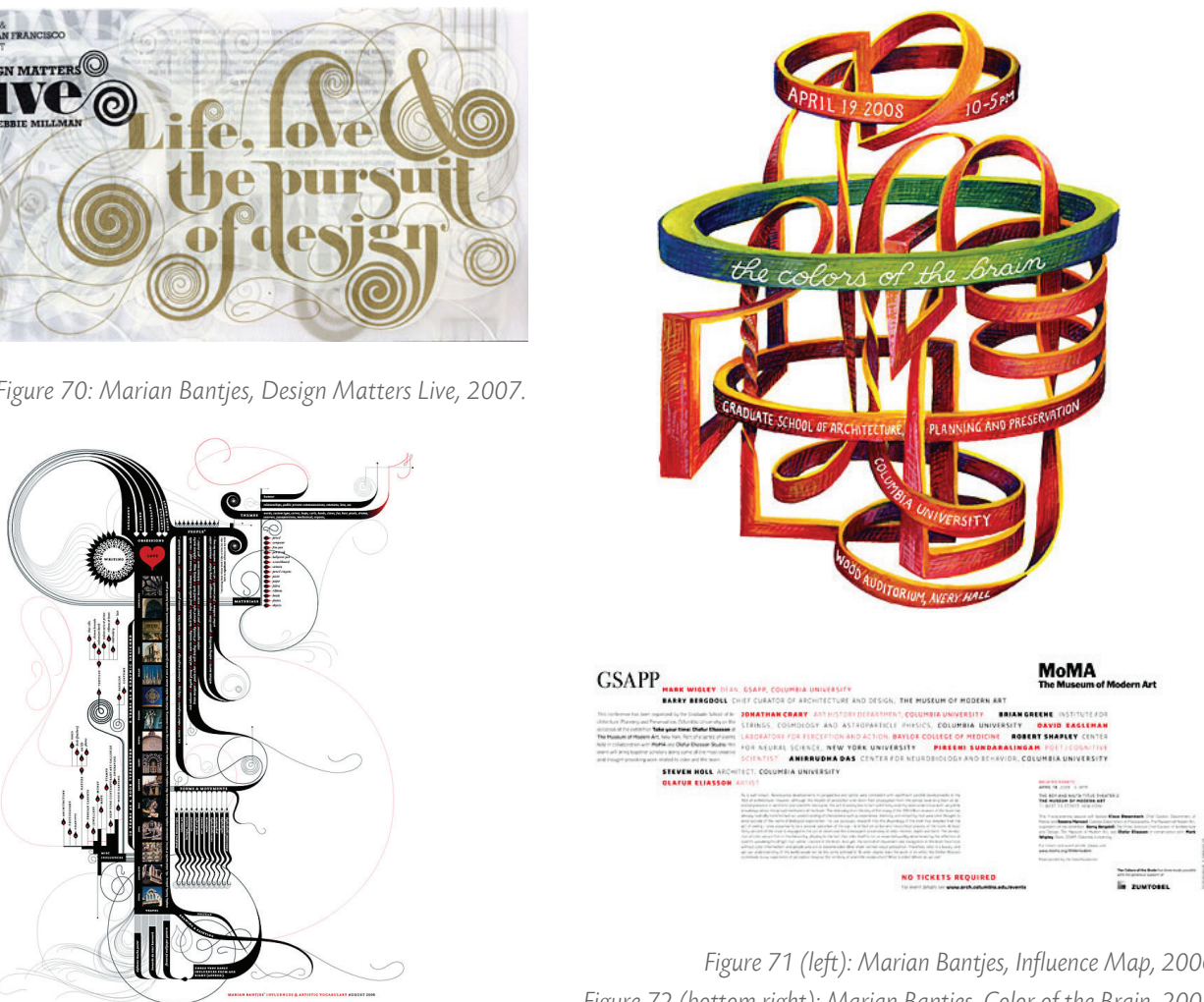

Figure 71 (left): Marian Bantjes, Influence Map, 2006. Figure 72 (bottom right): Marian Bantjes, Color of the Brain, 2008. 


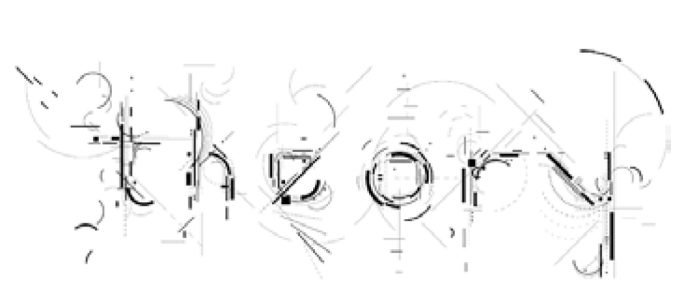

Figure 73: Marian Bantjes, WIRED: Theory, 2008

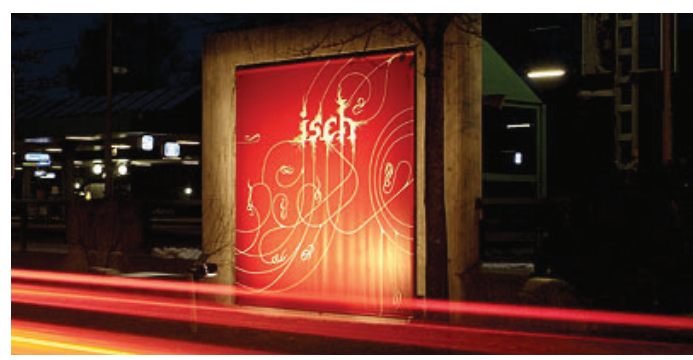

Figure 74: Marian Bantjes, Stefan Sagmeister, 20 Things in My Life I Have Learned So Far, 2006.

\subsection{TIME WARNER LOGO}

Steff Geissbuhler, a Swiss-American designer, was commissioned to create the Time Warner logo, when Time Inc. and Warner Communications decided to merge. Warner connected with entertainment and Time with journalism; the designer explained that he searched for common denominators of the companies by "looking and listening, reading and hearing, receiving and sending" (Geissbuhler, 2012). The logo combines the abstract image of an eye and ear, which are essential communication elements. They merge together within a spiral shape, nicely representing the connectivity of the companies and possibly speaking about their potential growth in the market.
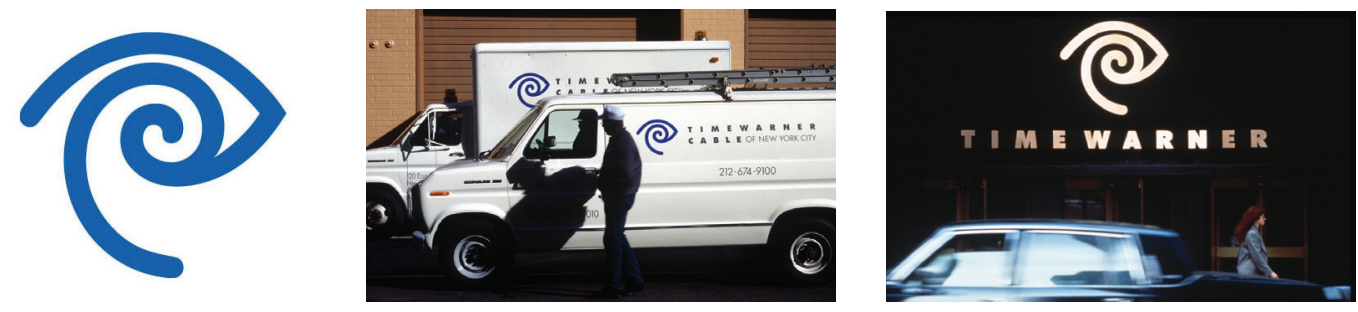

Figure 75 - 77: Steff Geissbühler, Time Warner Logo, 1989 - 2011.

\section{STACKING AND PACKING PATTERNS}

The third crucial group are patterns that stack and pack. According to Macnab (2012, p. 127), their quality is "to store the latent energy until it is needed while keeping it quite accessible". They visually appear as foursided shapes or hexagons (Fig. 74). In nature, they are created when elements of a different source are closely pressed together because of gravity or heat. Because of that, this pattern has no gaps or overlaps in their structure and so no excess in the form (Macnab, 2012, p. 127).

\section{Hexagons are in nature present in honeycombs; the structure allows bees to give "the maximum storage area for the least amount of wax" (BBC, 2013). They also appear as the structure of some molecules (Fig. 75), on a turtle's carapace, form our cells, viruses, and more.}

Snowflakes that branch in six directions are also based on the hexagon shape. In our physical world, we widely adopted the tessellated shapes in housing, on streets, and other manners of storage. On the intuitive level, they can thus present stability, reliability, and efficiency. In graphic design, they are widely used among different financially oriented companies to speak these qualities (Macnab, 2012, pp. 127-129). 


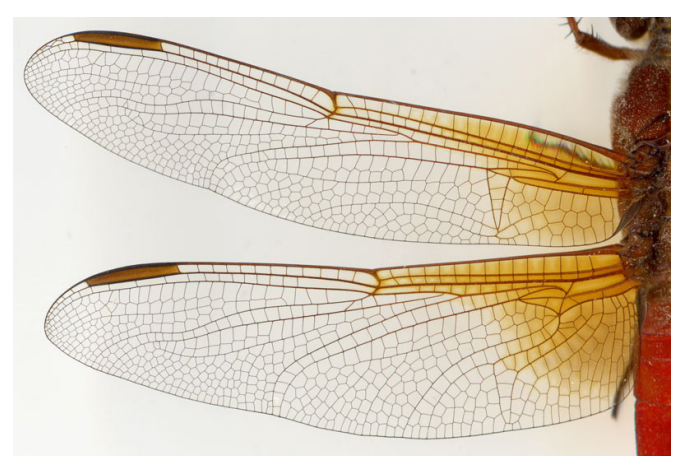

Figure 78: Tomasz Janiak, Dragonfly Wings, 2011

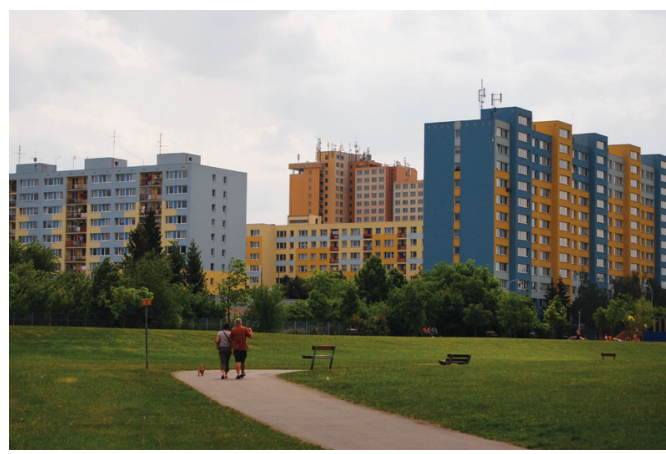

Figure 80: Maruša Račič, Prague's Housing Estate, 2012.

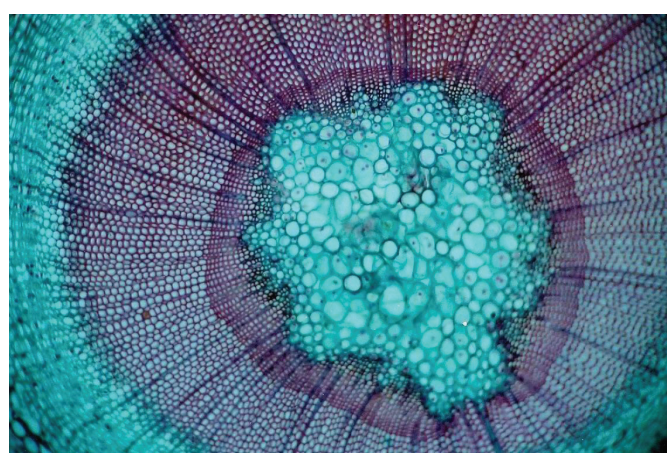

Figure 79: Berris Charnley, Microscope Image of Plant Vascular Bundles Under Differential Stain, 1999

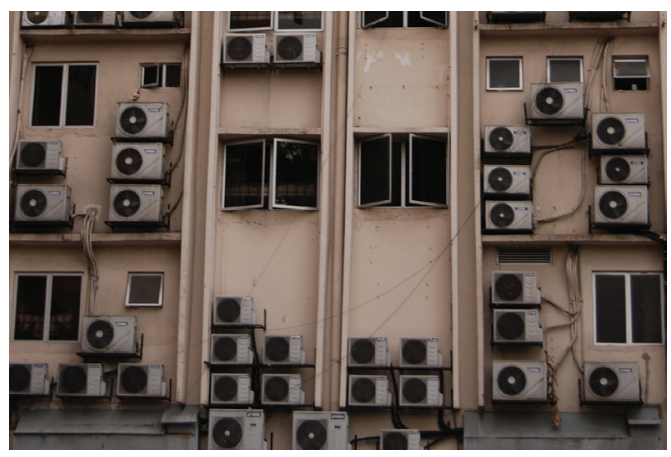

Figure 81: Maruša Račič, Air Conditioning, 2010.

Following bigger European Banks (Figs. 76-80) are some of the many examples that include these shapes into their logos to communicate the ideas of precision and efficiency. In the case of the Deutsche Bank logo, the inner element, presenting growth and development is kept in a frame, symbolising stability, security, and protection. The logo thus well embraces the philosophy of the bank that is "growth in a stable environment" (Deutsche Bank, 2011).

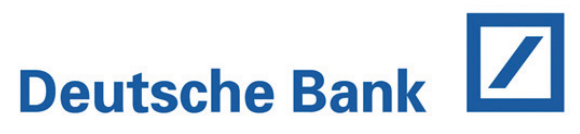

Figure 82: Anton Stankowski, Deutsche Bank Logo, 1974.

\section{$\mathrm{HSBC} 又$}

Figure 84: Henry Steiner, HCBC Logo, 1983.

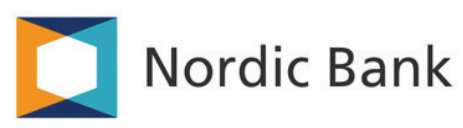

Figure 83: Communication Agency, Nordic Bank Logo, 2011.

\section{COMMERZBANK}

Figure 85: MetaDesign, Commerzbank Logo, 2009.

Oslo-based Neue Design Studio created a dynamic identity for the Nordkyn peninsula in Norway to promote touristic activities in this area (Figs. 80-83). Because Nordkyn is a place where nature is dominant (it is a remote mountainous area surrounded by arctic sea and ruled by extreme weather conditions), they created a logo generator that reflects weather statistics (Neue, 2012). The changes of the wind and temperature in the area change the logo accordingly while the "wind direction influences the form and the temperature influences the colour" (Nordkyn, 2013). The logo is based on a hexagonal shape. Along with weather characteristics of Nordkyn, it can also communicate the idea of a place that can offer diverse activities for tourists within its area. 

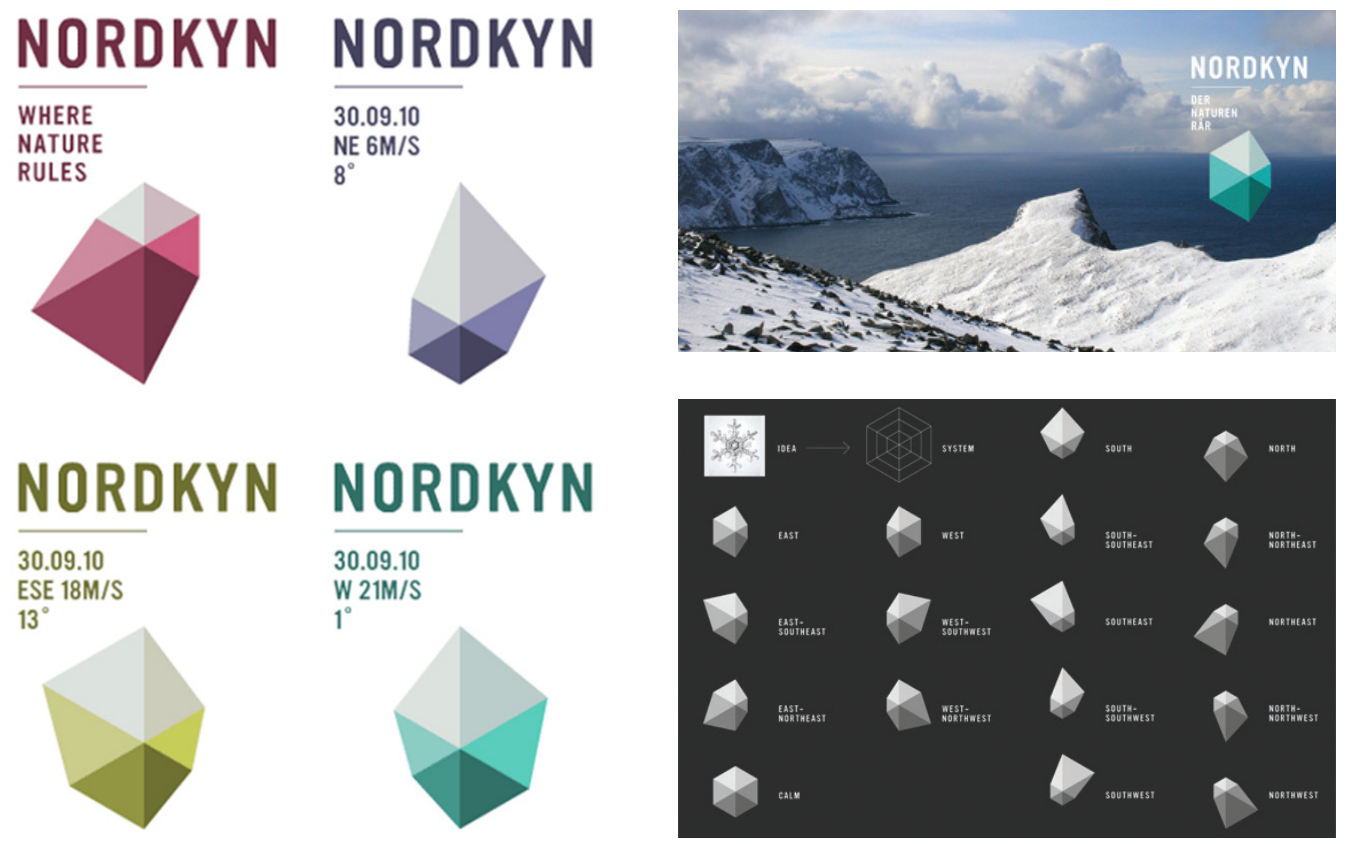

Figure 86 - 88: Neue, Visit Nordkyn, 2010

\section{CONCLUSION}

Throughout history, the on-going processes of nature were a referring background for our actions and creations. For millions of years, nature managed to match everything perfectly to its task so it is practical and economical, a great model to imitate. The inclusion of nature's pattern forms into the design of visual communications can to a certain degree play an important role in transferring the intuitive message because due to our evolutionary development, we can understand patterns' meanings on our subconscious level.

On the other hand, just forms of patterns are not enough for understandable visual communication because graphics consist of different elements, such as colour selection, textual support of imagery, composition of elements, and more. They all inseparably form a final piece and make it meaningful or not. We can thus not be entirely certain whether a piece of design can make a fluent relationship with a viewer strictly because of the inclusion of a pattern from nature. Because visual communication cannot be directly measurable in terms of their success in public, it can also be hard to prove whether a certain pattern form works well in transforming the message. Besides, the perception is also always to some degree open to subjective opinion and interpretation that varies according to individuals' different knowledge and experience. Due to the previously mentioned disconnection of man and nature on different levels, we can also doubt whether our primal intuition is still strong and pervasive like it used to be in the past. Has the different way of living also decreased our notions on an intuitive level? To some degree it has, which can consequently make patterns harder to notice and read.

Case studies indicate that the inclusion of pattern forms seems to be prevalent in logo design, as a logo form needs to reflect the philosophy of a company or product quickly and meaningfully with one single symbol. All the chosen examples in the paper are recognised as successful designs as they have won awards in competitions or attracted positive media attention. On the other hand, there are many other logos presenting the same services that do not include patterns from nature and still visually communicate the philosophy of a service very well. One cannot claim that fluent and understandable relationships between the viewer and the designed piece can be entirely achieved with weaving nature's patterns in visual communications, and natural patterns can definitely provide additional information that can play an important role in visualising a specific message. 


\section{REFERENCES}

Airey, D. (2010) Logo Design Love: A Guide to Creating Iconic Brand Identities. Berkeley: New Riders.

Bakkeslett, E. (2013) The Art of Seeing Patterns that Connect [Lecture to Cartographies of Hope: Change Narratives]. 17 January.

Baldwin, J. (2006) Visual Communication: From theory to practice. Ebrary. [Online]. Available at: http://site.ebrary.com (Accessed: 7 November 2012).

Bantjes, M. (2010) Intricate Beauty by Design [Lecture to TED] [Online]. Available at: http://www.ted.com/talks/ marian_bantjes_intricate_beauty_by_design.html (Accessed: 25 January 2013).

Bantjes, M. (2012) Print Magazine. [Online]. Available at: http://www.bantjes.com/project/print-magazinejulyaug-2006 (Accessed: 22 January 2013).

Bejan, A., Zane, J. P. (2012) Design in Nature: How the Constructal Law Governs Evolution in Biology. New York: Doubleday. Benyus, J. M. (2002) Biomimicry: Innovation, Inspired by Nature. 2nd edn. New York: HarperCollins Publishers.

Buchanan, P. (2012) 'The Big Rethink: Spyral Dynamics and Culture' The Architectual Review (23 November 2012) [Online]. Available at: http://www.architectural-review.com/the-big-rethink-spiral- dynamics-and-culture/8638840. article (Accessed: 21 January 2013).

Capelo, H. (2010) 'Symbols from the Sky' SEEDMAGAZINE.COM. [Online]. Available at: http:// seedmagazine.com/ content/article/symbols_from_the_sky (Accessed: 28 October 2012).

Deutsche Bank (2010) Brand History: The development of the Deutsche Bank Logo [Online]. Available at: https://www. db.com/en/media/Logo_History.pdf (Accessed: 23 January 2013).

Geissbuhler, S. (2011) Time Warner. [Online]. Available at: http://www.geissbuhler.com/31263/236593/ brandidentities/time-warner-and-time-warner-cable (Accessed: 23 January 2013).

Graham, W. (2010) The Art, Soul, and Science of Beholding Nature. [Online]. Available at: http://www.pat- ternsinnature. org/Book/WhyStudyPatterns.html (Accessed: 9 October 2012).

Harper, D. (2012) Online Etimology Dictionary. [Online]. Available at: http://www.etymonline.com/index. php?term=meandererallowed_in_frame=0 (Accessed: 18 October 2012).

Hekkert, P. (2006) ' Design aesthetics: principles of pleasure in design', Psychology Science, 44 (2), pp.157- 172 COE NEU [Online]. Available at: http://www1.coe.neu.edu/ yilin/IE7315_2010/Paper\%20Review\%20Schedule/Design\%20aesthetics\%20principles\%20of\%20pleasure\%20in\%20design.pdf (Accessed: 15 November 2012).

La Sagrada Família (2002) The Tree Structure. [Online]. Available at: http://www.sagradafamilia.cat/sf-eng/ docs_ instit/estructura2.php (Accessed: 25 January 2013).

Livio, M. (2003) The Golden Ratio: The Story of PHI, the World's Most Astonishing Number. New York: Broadway Books.

Macnab, M. (2008) Decoding Design: Understanding and Using Symbols in Visual Communication. Cinncinati: How Books.

Macnab, M. (2012) Design by Nature: Using Universal Forms and Principles in Design. Berkeley: New Riders.

Materia (2011) Awards. [Online]. Available at: http://www.materia.co.il/category/Awards (Accessed: 24 October 2012).

Meggs, B. P., Purvis, W. A. (2006) Meggs' History of Graphic Design. 4th edn. New Yersey: John Wiley er Sons.

Neue (2012) Visit Nordyn. [Online]. Available at: http://www.neue.no/index.asp?id=27415 (Accessed: 23 January 2013).

Nordkyn (2013) [Online]. Available at: http://www.visitnordkyn.com/ (Accessed: 23 January 2013).

Novak, M. M. (2004) Thinking in Patterns: Fractals and Related Phenomena in Nature. Ebrary. [Online]. Available at: http://site.ebrary.com (Accessed: 9 November 2012).

Oxford Dictionaries (2013) [Online]. Available at: http://oxforddictionaries.com/definition/english/spiral (Accessed: 19 January 2013).

Parkinson, M. (2010) Do-It-Yourself Billion Dollar Graphics: 3 Fast and Easy Steps to Turn Your Text and Ideas Into Persuasive Graphics. 2nd edn. Annandale: Pepperlip Press. 
Richworks (2011) Patterns in Nature: An Enigmatic Inspiration. 25 February [Online]. Available at: http:/ richworksin/2011/02/patterns-in-nature-an-enigmatic-inspiration/ (Accessed: 29 October 2012).

Root-Bernstein M. and Root-Bernstein R. (2011) 'What is the Pattern?' Imagine That. 11 March [Online]. Available at: http://www.psychologytoday.com/blog/imagine/201103/what-s-the-pattern (Accessed: 30 October 2012).

Sagmeister er Walsh (2012) Seed Logo. [Online]. Available at: http://www.sagmeisterwalsh.com/work/project/ seedlogo/ (Accessed: 22 January 2013).

Seed Media Group (2012) [Online]. Available at: http://seedmediagroup.com/scientific.html (Accessed: 20 November 2012).

SHL Telemedicine (2012) [Online]. Available at: http:/ /www.shl-telemedicine.com/uploads/medical\%20stud- ies/ Telemedicine\%20in\%20emergency\%20home\%20care\%20.pdf (Accessed: 26 October 2012).

Subha, S. (2012) ' Leaf-Inspired Solar Panels Make a Huge Increase in Power Generation' PreScounter Innovation Journal (31 May 2012) [Online]. Available at: http://www.prescouter.com/2012/05/leaf- inspired-solar-panels-make-ahuge-increase-in-power-generation/ (Accessed: 26 January 2013).

The Labyrinth: Walking Your Spiritual Journey (2012) [Online]. Available at: http://www.lessons4living.com/ labyrinth.htm (Accessed: 26 October 2012).

Veltman, H. K. (no date) Leonardo da Vinci: Studies of the Human Body and Principles of Anatomy. [Online]. Available at: http://www.mmi.unimaas.nl/people/veltman/articles/leonardo/Lenardo\%20da\%20 Vinci\%20Studies\%20of\%20 the\%20Human\%20Nody\%20and\%20Prinicples\%20of\%20Anatomy. html\#5 (Accessed: 16 October 2012).

Voelker, S. (2007) The Snow Crystal Principle. [Online]. Available at: http://www.svenvoelker.com/Design___ Sven_ Voelker_Studio_Berlin_E.html [Video clip] (Accesed: 4 November 2012).

Voelker, S. (2012) Work of a Graphic Designer Sven Voelker [Lecture to design]. 29 October.

Ward, G. (2006) Spirals: The Pattern of Existence. Bridgwater: Green Magic.

WOLDA (2012) 2008 Winners Showcase. [Online]. Available at: http://www.wolda.org/showcase/ professional /2008? page=12 (Accessed: 24 October 2012).

WOLDA (2012) 2010 Winners Showcase. [Online]. Available at: http://www.wolda.org/showcase/professional/2010 (Accessed: 24 October 2012).

Wolfram Mathworld (2013) Phyllotaxis. [Online]. Available at: Phyllotaxis http://mathworld.wolfram.com/ Phyllotaxis. html (Accessed: 22 January 2013).

\section{IMAGE LIST}

FIGURE 1: Etchverry, J. (2010) Geometric Painting, Rio Pinturas Canyon, Cave of the Hands, Pata [Online]. Available at: http://irudi.photoshelter.com/image/I0000RGqTVJZOKF8 (Accessed: 27 January 2012).

FIGURE 2: Račič, M. (2011) Present Day Graphic Designer, image taken on 3 October 2012.

FIGURE 3: Račič, M. (2010) Less Nature - Chaos on the Streets of Kuala Lumpur, image taken on 4 February 2010.

FIGURE 4: Račič, M. (2011) Ecologically Grown Food, image taken on 19 August 2010.

FIGURE 5: PUMA (2010) PUMA's Sustainability Efforts [Online]. Available at: http://counterkicks.com/2010/04/ puma-clever-little-bag/ (Accessed: 27 January 2013).

FIGURE 6: SMIT (2011) Solar cells, Inspired by Leaves [Online]. Available at: http://s-m-i-t.com/\#projects_target (Accessed: 27 January 2013).

FIGURE 7: Sagrada Familia (2012) Interior [Online]. Available at: http://www.lifestyleflash.com/2012/a-photodiary-from-barcelona/barcelona-sagrada-familia-interior/ (Accessed: 24 January 2013).

FIGURE 8: Račič, M. (2011) A Branching Tree, image taken on 16 November 2011.

FIGURE 9: Cassandre Mouron, A. (1927) Nord Express [Colour lithograph]. $75 \mathrm{~cm}$ x $105 \mathrm{~cm}$ [Online]. Available at: http:// collections.vam.ac.uk/item/O89673/nord-express-poster-cassandre-adolphe- mouron/ (Accessed: 27 January 2012). 
FIGURE 10: Rail Europe (2009) Rail Europe Web Site [Online]. Available at: http:/ /libn.com/ thetechnofile/2009/07/07/fatwire-rides-the-european-rails/ (Ac- cessed: 24 January 2013).

FIGURE 11: Meggs, B. P., Purvis, W. A. (2006) Meggs' History of Graphic Design. 4th edn. New Yersey: John Wiley er Sons, p. 23, image.

FIGURE 12: Račič, M. (2011) Open Landscape l, image taken on 16 September 2011.

FIGURE 13: Leong, M. (2012) Mong Kok District, Hong Kong [Online]. Available at: http://photography. nationalgeographic.com/photography/photo-of-the-day/mong-kok- leong/ (Accessed: 23 January 2013).

FIGURE 14: Moosey's Country Garden (2010) Buff Beauty Rose Flower [Online]. Available at: http:/ /images. mooseyscountrygarden.com/roses/20/ (Accessed: 23 January 2013).

FIGURE 15: Annukka, S. (2012) Sanna Annukka for Marimekko [Online]. Available at: http://www.sanna-annukka. com/?_a=sannaersanna_page=blog (Accessed: 23 January 2013).

FIGURE 16: Aelst, K. (2007) Right Middle Finger [digital c-print]. 40 × 30"[Online]. Available at: http:/ /www.kevinvanaelst.com/photoc.html (Accessed: 24 January 2013).

FIGURE 17: National Institute of Standards and Technology (no date) DNA [Online]. Available at: http://www.nist. gov/oles/forensics/biology_dna.cfm (Accessed: 24 January 2013).

FIGURE 18: Semonov, S. (2012) New York Central Park from Above [Online]. Available at: http:/ /www.thepanoawards.com/ (Accessed: 24 January 2013).

FIGURE 19: Račič, M. (2013) Seashells, image taken on 24 January 2013.

FIGURE 20: Cole, R. T. (2011) Lightning, Arizona [Online]. Available at: http://photography.nationalgeographic. com/wallpaper/photography/photos/best-pod-april-2011/lightning-arizona/ (Accessed on: 24 Janu- ary 2013).

FIGURE 21: Račič, M. (2010) Mexican Agava, image taken on 27 September 2010.

FIGURE 22: Račič, M. (2009) Bromo Volcano, image taken on 7 August 2009.

FIGURE 23: Johns, C. (no date) Cheetah [Online]. Available at: http://animals.nationalgeographic.com/animals/ photos/cheetahs/ (Accessed on: 24 January 2013).

FIGURE 24: Haas, B. R. (2008) Bay of Bothnia, Sweden [Online]. Available at: http://travel.nationalgeographic. com/ travel/countries/arctic-aerial-photos/\#/vikings-book-06_27233_600×450.jpg (Accessed on: 24 January 2013).

FIGURE 25A: Da Vinci, L. (1504) A map of the Arno west of Florence [pen and ink]. $42.2 \times 24.2 \mathrm{~cm}$ [Online]. Avail- able at: http://www.royalcollection.org.uk/collection/912678/a-map-of-the-arno-west-of-florence (Accessed on: 24 January 2013).

FIGURE 25B: Da Vinci, L. (1508) The veins of the Arm [pen and ink]. $19.2 \times 14.1 \mathrm{~cm}$ [Online]. Available at: http:// www. royalcollection.org.uk/collection/919027/recto-the-veins-of-the-arm-verso-notes-on-the- death-of-a-centenarian (Accessed on: 24 January 2013).

FIGS. 26-28: 180 TBWA, China (2008) Impossible is Nothing - Adidas Campaign [Posters]. Available at: http:/ /www. tamcao.com/blog/archives/244. (Accessed on: 24 January 2013).

FIGURE 29: Račič, M. (2009) Bananas - Connections of Shapes, Colours and Numbers, image taken on 18 Avgust 2009.

FIGURE 30: Cuko, E. (2011) Sight [Online]. Available at: http://www.sciencelearn.org.nz/Science-Stories/OurSenses/Sci-Media/Images/Sight (Accessed on: 25 January 2013).

FIGURE 31: Melford, M. (no date) Owyhee River [Online]. Available at: http://ngm.nationalgeographic. com/2011/11/americas-wild-rivers/melford-photography\#/03-owyhee-river-idaho-670.jpg (Ac- cessed on: 25 January 2013).

FIGURE 32: Račič, M. (2010) Traffic Flow, image taken on 14 September 2010.

FIGURE 33: MathWorld (no date) Fractals and Self-similarity [Online]. Available at: http://mathworld.wolfram. com/ Fractal.html (Accessed on: 25 January 2013).

FIGURE 34: Access Excellence Classic Collection (no date) Arterial and Venous Systems [Online]. Available at: http:/ / www.accessexcellence.org/AE/AEC/CC/heart_anatomy.php (Accessed on: 25 January 2013).

FIGURE 35: Anatomical Institute Bern (no date) Human Lungs [Online]. Available at: http://users.rcn.com/jkim- ball. ma.ultranet/BiologyPages/P/Pulmonary.html (Accessed on: 25 January 2013). 
FIGURE 36: Jakoube, H. (2013) A Leaf [e-mail to Maruša Račič], image taken on 7 February 2013.

FIGURE 37: Oskin, A. (2013) Snow Crystal [Online]. Available at: http://en.www.lensart.ru/user-uid-1676.htm (Accessed on: 25 February 2013).

FIGURE 38-41: Google Earth (2010-2012) Fractals on Earth - Burma, Egypt, Greenland and Austria [Online]. Available at: http://paulbourke.net/fractals/googleearth/ (Accessed on: 25 January 2013).

FIGURE 42: Burtynsky, E. (2003) Highway \#1 [Online]. Available at: http://www.welovedc.com/2009/10/02/ edward-burtynsky-oil/ (Accessed on: 26 January 2013).

FIGURE 43: Google Earth (2011) Fractals on Earth - Spain [Online]. Available at: http:/ / paulbourke.net/fractals/ googleearth/ (Accessed on: 26 January 2013).

FIGURE 44: Lanting, F. (no date) Meandering River, Manu National Park, Peru [Online]. Available at: http:/ /franslanting.photoshelter.com/image/100009tC22JyKkuQ(Accessed on: 26 January 2013)

FIGURE 45: Guido Mocafico (2003) Rhynchophis Boulengeri [Online]. Available at: http://www.guidomocafico. com/ see4.html (Accessed on: 26 January 2013).

FIGURE 46: Hossler, F. (no date) Human Brain [Online]. Available at: http://science.nationalgeographic.com/science/photos/brain/\#/human-brain_1001_600x450.jpg (Accessed on: 26 January 2013).

FIGURE 47: Greek Coins (67 B.C.) Cretan Coin - The Minotaur's Labyrinth [Online]. Available at: http:/ /www.greekcoins.net/ancient-coins-depictions/ (Accessed on: 26 January 2013).

FIGS. 48-51: Dan Alexander $e$ Co. (2005) Shahal Telemedicine Identity [Online]. Available at: http:/ /www.daitd. com/ index.php?id=33 (Accessed on: 26 January 2013).

FIGURE 52: Voelker, S. (2012) Suzuki Brand Manual [e-mail to Maruša Račič].

FIGURE 53: Peek-a-boo (2010) Micham 200 [Online]. Available at: http://www.materia.co.il/page/Mitcham-200 (Accessed on: 26 November 2012).

FIGURE 54: Free Hospital for Women, Brookline, Massachusetts (1956) Developmental Stage in Human Embryo [Online]. Available at: http://www.ehd.org/developmental-stages/stage14.php (Accessed on: 26 January 2013).

FIGURE 55: Krommes, B. (2011) Swirl by Swirl [Illustration] [Online]. Available at: http:/ /www.bethk- rommes.com/ illustration/reviews-for-swirl-by-swirl-spirals-in-nature (Accessed on: 26 January 2013).

FIGURE 56: Lucapost (2007) Sunflower: The Fibonacci Sequence. Flickr [Online]. Available at: http:/ /www.flickr. com/ photos/lucapost/694780262/sizes/I/in/photostream/ (Accessed on: 26 January 2013).

FIGURE 57: NASA, ESA, The Hubble Heritage Team (2010) Spiral Galaxy NGC 1376, [Online]. Available at: http:/ / heritage.stsci.edu/2010/00/index.html (Accessed on: 26 January 2013).

FIGURE 58: Plavecky, D. (2012) Going up [e-mail to Maruša Račič], image taken on 4 January 2012.

FIGURE 59: Beck D. E., Cowan C. C. (1996) Spiral Dynamics [Online]. Available at: http:/ /www.architectural- review. com/the-big-rethink-spiral-dynamics-and-culture/8638840.article (Accessed on: 26 January 2013).

FIGURE 60: Račič, M. (2013) Divine Proportion.

FIGURE 61: Kepler's Discovery (no date) The Golden Rectangle [Online]. Available at: http://www.keplersdiscov- ery. com/DivineProportion.html (Accessed on: 27 January 2013).

FIGURE 62: Werner, P. (no date) Nautilus [Online]. Available at: http://www.keplersdiscovery.com/DivineProportion.html (Accessed on: 27 January 2013).

FIGURE 63: Van Gogh, V. (1889) The Starry Night [Oil on Canvas]. 73.7 × $92.1 \mathrm{~cm}$ [Online]. Available at: http:// www. moma.org/collection/object.php?object_id=79802 (Accessed on: 27 January 2013).

FIGURE 64: Rbnptrs (2009) Column. Flickr [Online]. Available at: http://www.flickr.com/photos/rbnptrs/3243444219/ (Accessed on: 26 January 2013).

FIGURE 65-67: Sagmeister $\Theta$ Walsh (2005) Seed logo [Online]. Available at: http:/ / www.sagmeisterwalsh.com/ work/ project/seed-logo/ (Accessed on: 26 January 2013).

FIGURE 68-69: Bantjes, M. (2006) Print Magazine Jul/Aug 2006 [Online]. Available at: http:/ /www.bantjes.com/project/print-magazine-julyaug-2006 (Accessed on: 26 January 2013). 
FIGURE 70: Bantjes, M. (2007) Design Matters Live [Online]. Available at: http://www.bantjes.com/project/de- signmatters-live (Accessed on: 26 January 2013).

FIGURE 71: Bantjes, M. (2006) Influence Map [Online]. Available at: http://www.bantjes.com/project/influencemap (Accessed on: 26 January 2013).

FIGURE 72: Bantjes, M. (2008) Colors of the Brain [Online]. Available at: http://www.bantjes.com/project/colorsbrain (Accessed on: 26 January 2013).

FIGURE 73: Bantjes, M. (2008) WIRED: Theory [Online]. Available at: http:/ /www.bantjes.com/node?page=2 (Accessed on: 26 January 2013).

FIGURE 74: Bantjes, M. (2006) Stefan Sagmeister: 20 Things in My Life I Have Learned so Far [Online]. Available at: http://www.bantjes.com/node?page=2 (Accessed on: 26 January 2013).

FIGS. 75-77: Geissbühler, S. (1989-2011) Time Warner Logo [Online]. Available at: http://tomaszjaniak.files.wordpress.com/2011/04/dragonfly_wing_001.jpg (Accessed on: 26 January 2013).

FIGURE 78: Janiak, T. (2011) Dragonfly Wings [Online]. Available at: http://tomaszjaniak.files.wordpress. com/2011/04/dragonfly_wing_001.jpg (Accessed on: 26 January 2013).

FIGURE 79: Charnley, B. (1999) Microscope Image of Plant Vascular Bundles Under Differential Stain [Online]. Available at: http://ipbio.org/ (Accessed on: 26 January 2013).

FIGURE 80: Račič, M. (2012) Prague's Housing Estate, image taken on 22 May 2012.

FIGURE 81: Račič, M. (2010) Air Conditioning, image taken on 17 September 2010

FIGURE 82: Stankowski, A. (1974) Deutsche Bank Logo [Online]. Available at: http://www.designersjournal.net/ jottings/heroes-anton-stankowski (Accessed on: 26 January 2013).

FIGURE 83: Communication Agency (2011) Nordic Bank Logo [Online]. Available at: http:/ /www.communicationagency.com/ (Accessed on: 26 January 2013).

FIGURE 84: Steiner, H. (1983) HSBC Logo [Online]. Available at: http:/ / www.yourlogoresources.com/hsbc-logo/ (Accessed on: 26 January 2013).

FIGURE 85: MetaDesgin (2009) Commerzbank Logo [Online]. Available at: http://www.underconsideration.com/ brandnew/archives/commerzbank_folds.php(Accessed on: 26 January 2013).

FIGS. 86-88: Neue (2010) Visit Nordkyn [Online]. Available at: http://ipbio.org/ (Accessed on: 26 January 2013) 